\title{
ECONOMIC HISTORY
}

\section{WORKING PAPER SERIES}

FOREIGN DIRECT INVESTMENTS AND

INTELLECTUAL PROPERTY RIGHTS. INTERNATION AL INTANGIBLE ASSETS IN SPAIN CIRCA 1820-1939

Patricio Sáiz (UAM) and Rafael Castro (UAM)

Working Paper 02/2013

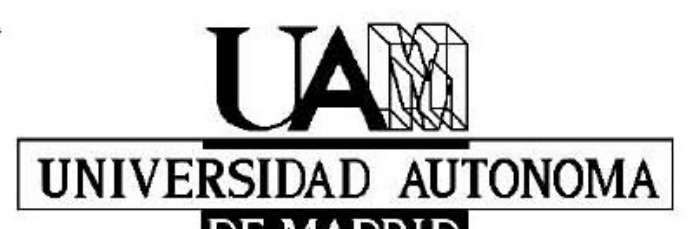

DE MADRID 


\title{
Foreign Direct Investment and Intellectual Property Rights.
}

International Intangible Assets in Spain circa 1820-1939

\author{
Patricio Sáiz and Rafael Castro
}

Universidad Autónoma de Madrid

patricio.saiz@uam.es

rafael.castro@uam.es

\section{ABSTRACT:}

We devote this paper to reflecting on Foreign Direct Investment (FDI) and Intellectual Property Rights (IPRs) in the long run, particularly analyzing the case of Spain during the nineteenth and twentieth centuries. Although the interactions between IPRs and FDI have attracted significant research efforts in distinct economic and business areas, the results lack permanent answers. Our findings demonstrate that, from a macro-level perspective, 1) FDI and IPRs are effectively related in the long term; 2) weak IPR protection does not seem to have stopped FDI; and 3) the countries with major FDI in Spain were less worried about IPR management than others with less FDI.

JEL: F21, N73, N74, O34

\section{KEYWORDS:}

IPR Management; Patents; Trademarks; FDI; International Business History 


\section{Introduction}

The relation between FDI and IPRs is a central point in today's concerns about economic development. FDI has historically been a significant component of modern economic growth and has benefited both pioneer nations looking for new markets and developing and lagging countries lacking in capital, skills, technologies, or entrepreneurship. It is commonly accepted that foreign investment decisions depend on ownership, location, and internationalization advantages. ${ }^{1}$ The ownership value is also, if not mainly, related to intangible assets such as innovative, mercantile, and organizational skills, that other firms and investors do not have, as proposed first by Stephen H. Hymer ${ }^{2}$ and then by the resource-based and evolutionary theories of the firm. ${ }^{3}$ Indeed, during the first stages of the investment development path, FDI usually takes place through the acquisition of intangible assets such as patents and trademarks. ${ }^{4}$ Thus, ownership should also be related to the level and scope of IPRs in the recipient countries, whose patent and trademark institutions may be designed in distinct ways for favouring or retarding foreign applications. That might also influence the receptivity and location processes, ${ }^{5}$ even if, as Chandler suggests "the research organizations of modern industrial enterprises remained a more powerful force than patent laws in assuring the continued dominance of pioneering mass production firms in concentrated industries.”,

Although dozens of works have engaged in exploring such a complex trade-off between FDI and IPRs, there are no definitive conclusions yet, as it usually occurs in social science key discussions. Thus, it is possible to find both theoretical and empirical studies supporting the assertion that stronger IPRs increase FDI and just the opposite, while others eclectically claim that many and distinct institutional and economic factors concerning source and recipient countries determine that relationship. It seems plausible that without assuring certain institutional stability and a private property rights minimum (for tangible and intangible assets) it may be difficult to encourage FDI. In fact, the notion that IPR reinforcement favors FDI and technology transfer has predominated among the specialized literature. ${ }^{7}$ Nevertheless, some of these scholars qualify their findings and results depending on the type of industry or on the recipient country development level. For instance, based on recent US, German, and Japanese FDI data, Mansfield showed that firms in the chemical and machinery and equipment industries reported that IPRs strongly influence their FDI decisions, while companies in transport, metals, food, sales, and distribution do not. ${ }^{8}$ Regarding the development level, although some works find a positive correlation between IPRs and FDI in developed countries, they also show that less-developed economies may benefit from a weaker IPR level and that the absence of sufficient IPR protection does not reduce FDI in certain countries. ${ }^{9}$ Furthermore, other analyses have demonstrated that in certain circumstances low-level IPRs not only do not reduce but even increase FDI to maintain control over production knowledge ${ }^{10}$ and that strengthening IPRs above a certain point could actually decrease FDI, because it could be replaced by licensing. ${ }^{11}$ 
Other scholars are more critical of IPRs than the mainstream economic thought. Boldrin and Levine strongly support the notion that IPR protection is overestimated and that it should be widely reduced everywhere to promote social good, especially in a context of global innovation markets. ${ }^{12}$ In some of their recent works, they reflect on IPR and FDI links and, although admitting that small countries with very low IPR protection may experience certain FDI inflows, they claim that it would not be scalable and that continuous strengthening of IPRs would just lead to a Nash equilibrium solution concerning international FDI. Applying a zerosum-game logic, intangible assets' owners would prefer to locate in countries with strong IPRs, which increases the stock of capital in the country but reduces it everywhere else, especially in countries with low IPRs. In the absence of international cooperation, the tendency will be to strengthen IPRs everywhere, although the total amount of FDI would be the same as if all countries were guaranteeing low-level IPRs and not strong monopolies. ${ }^{13}$ In fact, some previous empirical work that analyzed US investments in 33 developed countries claims similar findings, sustaining that IPR (patent) protection was insignificantly correlated with FDI inflows and that developing economies should be well aware of these results. ${ }^{14}$

Thus, the effects of IPRs on FDI seem to have been theoretically ambiguous ${ }^{15}$ and empirically contradictory. ${ }^{16}$ Moreover, recent studies stress the need to take into account multiple unobserved country-specific factors (institutions, culture, development level, schooling standard, imitative capacities, social capital level etc.) that strongly determine the relationship between the level and scope of IPRs and FDI. ${ }^{17}$ Herein we claim that historical dynamics and long-term approaches have also to be included both in the theoretical framework and, especially, in the empirical research. We lack of detailed long-term analyses and data that would, first, contribute to the development of general theories concerning FDI and IPR phenomena, and second, allow for testing the distinct theoretical hypothesis. In fact, the majority of today's research focuses only on recent periods and enquires just about how IPRs influence FDI. It is necessary to reverse the question and explore the historical evidence.

Based in our research, we claim that when the long-run is taken into account FDI and IPR extension can be taken as parts of the same co-evolutionary process, in which the growing expansion of international business (IB) throughout the nineteenth century, and especially corporate and multinational IB from the 1870s onwards, turns into the key explanation for the understanding of local IPR reinforcement and international IPR agreements. Hence, our initial hypothesis is that it was the expansion of IB and capitalism which drove the growth and widening of IPRs and not the opposite. The business globalization required and requires a worldwide defense of intangible assets for maximizing revenues. This process has completely spread throughout the world during the twentieth century until reaching the current international situation and concerns, in which many scholars continue to make themselves the erroneous questions. IPRs, as we understand them nowadays, are a consequence, more than one of the 
causes, of FDI expansion. They are a strategic tool that MNEs have contributed to develop and have learnt to manage and that FDI recipient countries were able to tune for totally favoring foreign investors or for making difficult large foreign intellectual monopolies.

As far as we know, there are no previous long-term theoretical or empirical analyses of FDI and IPR links such as the one we have carried out herein based on significant FDI proxies and outstanding IPR data for Spain, a lagging country of the European periphery that was the recipient of notable European and North American FDI during the nineteenth and twentieth centuries. Spain developed a "hybrid" IPR system that, while fitting international standards, required actual investments to maintain intellectual monopolies. In this work, we draw a widespread picture of the historical role and origin of foreign capital in the Spanish economy and compare it with the evolution of foreign IPRs in the country from a macro-level perspective. Thanks to painstaking and long-term research conducted through thousands of original files at the archive of the Spanish patent and trademark office, we were able to study thoroughly all the intellectual monopolies granted to foreigners in Spain, between 1820 and 1939 for patents and between 1850 and 1916 for trademarks, which includes accurate information on applicants, on protected technologies and products, and also on monopolies' actual duration, compulsory working clauses' consequences, or license and assignment practices.

Thus, through this work we want, first, to find out if the character of the Spanish IPR regime had any influence on the evolution of FDI in the long-run; second, to deepen into the relationship between FDI and foreign IPRs in Spain regarding countries of origin and sectors of activity; and, finally, to disentangle distinct IPR management strategies followed by foreign applicants from countries with different investment interests in Spain. In order to do so Section 2 examines how IPRs progressively became a global issue just as the international economy expanded; Section 3 characterizes foreign investments in Spain in the long term; Section 4 provides aggregate data on the evolution of foreign patents and trademarks in Spain before World War II (WWII); Section 5 studies foreign IPR duration and licensing as a way of measuring distinct IPR strategies; and Section 6 provides several concluding remarks.

\section{Global IPRs for global FDI}

In the last 200 years, the history of FDI has, overall, followed an upward but not linear trend with major ebbs and flows. Based on the booming of the Atlantic economy in the eighteenth century, which created lucrative opportunities for merchants, the processes of national market integration and international globalization accelerated rapidly in the nineteenth century as the technological changes of the First Industrial Revolution and, especially, those of the second resulted in a reduction of transport and communication costs. The spread of modern economic growth created a worldwide search for markets and raw materials: the first globalization was 
born, reinforced by the spread of multinational corporations, ${ }^{18}$ imperialism, ${ }^{19}$ and the adoption of the gold standard. ${ }^{20}$ By 1914, a remarkably integrated global economy was in place, not only in capital flows but also in trade, migration, prices, or technologies.

The outbreak of World War I (WWI) broke this trend and was the beginning of a progressive dismantling of the global economic framework, which was definitively destroyed by economic and political shocks. ${ }^{21}$ The European FDI was eliminated through wartime requisition and the Russian Revolution. The Wall Street crash of 1929 represented the "coup de grace” for the global economy, ${ }^{22}$ which collapsed during the 1930s and WWII. Barriers to the mobility of people, trade, capital, knowledge, and technologies were erected, despite FDI proving flexibility through new corporate strategies and cartel agreements. ${ }^{23}$

During the so-called golden age of capitalism, slow rebuilding of the global economy took place, with the progressive removal of trade barriers and exchange controls, at least between North America and Western Europe. ${ }^{24}$ MNEs, the primary drivers of the flows of foreign investment, spread throughout the globe. However, almost half of the world economy (USSR, China, and other communist countries) remained disconnected from global capitalism, and significant restrictions on FDI remained. Despite the oil shocks of the 1970s, MNEs resumed strategies of building integrated businesses in some regions, such as Europe. An integration that became global from the 1980s and above all the 1990s. As Jones points out, by the twenty-first century, almost two-fifths of world trade alone was intra-firm, even surpassing its importance in $1913 .{ }^{25}$ MNEs were, once again, the primary drivers of the integration of countries such as China into the world economy. However, the influence of location and geography seemed as strong as ever.

In this long-term framework, an increasing international flood of foreign investments demanded to improve legal certainty for businesses and firms among distinct countries. Gradually, North Atlantic economic, political, and legal systems converged in elementary points during the nineteenth and twentieth centuries. As in other fields, private property rights soon emerged as the most suitable way to manage intangible goods (facilitating, therefore, the “ownership” factor). Given the increasing economic significance of inventions, new ideas, distinctive signs, or writings, and given the difficulties of excluding imitators and thus encouraging innovators, patent, copyright, and trademark laws were progressively enacted by emerging liberal governments. The changes had begun in England when the 1624 Statute of Monopolies was passed and the privileges granted to inventors of new technologies were distinguished from additional arbitrary economic privileges ${ }^{26}$ Although it was not perfect, and perhaps because of that, the Statute remained in force until 1852, providing a basic framework for invention protection and diffusion during the Industrial Revolution.

The newly independent United States in $1790^{27}$ and the revolutionary France in $1791^{28}$ were the following countries that established fully modern patent laws. During the first half of 
the nineteenth century, many other countries, such as the Netherlands (1809), Austria and Hungary (1810), Sweden (1819), Portugal (1837), Spain (1811 to 1826), distinct Italian and German states existing prior to their unifications, and several new Latin American nations, enacted patent legislation. From 1850 to WWI, patents were in force in practically all relevant economies. ${ }^{29}$ Furthermore, throughout the twentieth century, guarantees for the ownership of inventions and IPRs in general were widened and adapted to an increasingly complex industrial and economic world, progressively led by corporations and MNEs.

New modalities, such as trademarks, utility models, industrial designs, and commercial names, appeared. Distinctive signs, for instance, had traditionally been used for highlighting local craft workshops and goods in the guild system during the "Ancient Regime" as well as outside guilds in the eighteenth century. ${ }^{30}$ During the nineteenth century, as occurred with invention protection, albeit belatedly, fully modern trademark laws were passed in numerous countries and national registries were established. To our current knowledge, Spain pioneered modern national trademark legislation in 1850, followed by France in 1857 and several other economies during the second half of the nineteenth century, such as the United States (1870) and the United Kingdom (1875-1876). Austria, Belgium, the Netherlands, Sweden, Norway, Portugal, and some German and Italian states had already enacted trademark laws in 1862. ${ }^{31}$

The so-called Second Industrial Revolution (SIR), from the 1870s and 1880s onwards, implied well-known technological, economic, and institutional shifts that also affected IPRs. While an international and integrated market for products and factors soared, protectionist and nationalist policies re-entered the stage. Firms progressively changed their commercial and productive strategies towards innovation, product differentiation, international investments, and the establishment of foreign subsidiaries. In this process, defending IPRs globally became crucial. Although the majority of countries guaranteed "de facto" intellectual protection to foreigners, aliens had not always been treated as nationals in all patent and trademark laws, especially at early stages of legal development. ${ }^{32}$ Thus, the globalization of IPRs began first by including foreigners in national legislation, second through the means of bilateral agreements among distinct countries for respectively guaranteeing the same rights to citizens from both nations involved, and finally by the signing of a general international treaty wholly focused on the subject: the 1883 International Union for the Protection of Industrial Property, which remains in force today.

E. Penrose's classical study, Economics of the International Patent System, ${ }^{33}$ profusely describes the path to the agreement. US complaints about Austrian protection of American inventors at the International Exhibition that took place in Vienna in 1873 led to the first international conference. Although it was not an official meeting, representatives of 13 countries, dominated by Germans, discussed and agreed several points concerning international patent protection and empowered a preparatory committee for further understanding. The 1878 
Paris Conference was the next round, again unofficial and in connection with another international exhibition. This time, the French thesis dominated the conference, which clearly exalted inventors' natural property rights and advocated an international union on patents and industrial property. A permanent international commission prepared a project for such a treaty and called for an official conference in Paris in 1880, which was attended by 19 governments. After revisions and amendments, the Convention of Paris of March 20, 1883 for an International Union for the Protection of Industrial Property was finally approved and signed, and ratifications were exchanged in 1884 by 14 countries. $^{34}$

This first agreement showed a "contradiction" that still occurs frequently nowadays between the necessity for negotiating an international common framework, which usually might benefit all the players as a group, and the strong will for defending particular domestic interests. The notion of a "universal law" on IPRs was soon overcome, once realizing the differences among distinct legal traditions, patent and trademark requirements, and economic histories. Thus in 1883-4, only general principles emerged regarding national treatment for foreigners (Article 2), priority rights for registering previous patents, trademarks, or industrial designs in the signing countries (Article 4), ${ }^{35}$ security that importing own patented objects or under own trademarks from abroad would not forfeit IPRs (Article 5), or temporal protection in international exhibitions (Article 11).

Nonetheless, there was no initial agreement to abolish controversial points, such as compulsory licenses if the "public" (national) interests should require them or the right to revoke patents and trademarks if they were not implemented. In many countries, the national legislation obliged IPR owners to invest in and manufacture protected machines, procedures, or products within the country, otherwise losing the monopoly. The right to establish such compulsory working clauses was finally included in the 1883 agreement (Article 5) with the opposition of Belgium and the United Kingdom, and in further treaty revisions with the opposition of Italy (1886) and the United States (1890). In the 1911 revision, Germany and the United States (two countries with increasing investments and interests abroad) fought against compulsory working clauses with the strong opposition of the Dutch, Spanish, Australians, French, and, this time, also the British. The final results were 1) the introduction of at least a three-year period for working the patent and 2) the possibility for the patentee of justifying his failure to work. Finally, in a 1925 conference, patent revocation because of compulsory working clauses was substituted with the mandatory offer of patent licenses; only if the licenses were not adequate could patents be revoked. ${ }^{36}$

The 1883-4 Union also established an International Bureau for the Protection of Industrial Property in Bern (Switzerland), which was the predecessor of the current World Intellectual Property Organization (WIPO), as well as the possibility of further amendments and adhesions. Besides the referred-to amendments of Rome 1886, Madrid 1890, Brussels 1897- 
1900, Washington 1911, and The Hague 1925, the treaty was revised and developed in London 1934, Lisbon 1958, and Stockholm 1967 and 1979, although the basic principles established at the end of the nineteenth century currently remain in force in 174 signing countries. In 1934, for instance, the inventor's right to be mentioned in the patent was introduced, which clearly demonstrates the extent to which corporations had already captured the international system. Besides, complementary agreements emerged in some of the conferences or previous meetings, such as the 1891 Madrid Arrangements 1) for the Repression of False Indications of Source on Goods and 2) for the International Registration of Trademarks; the 1925 Hague Agreement for the International Deposit of Industrial Designs and Models; the 1958 Lisbon Agreement for the Protection of Appellations of Origin and their International Registration; the 1977 Budapest Treaty for International Recognition of the Deposit of Microorganisms for Patent Purposes; the 1989 Madrid Protocol relating to the Madrid Agreement concerning the International Registration of Marks; and the significant 1970 Washington Patent Cooperation Treaty (PCT). Similarly, from 1886 onwards, several agreements focusing on copyright (literary and artistic works, phonograms, etc.) completed the IPR extension and globalization. ${ }^{37}$

Some of the aforementioned treaties and their revisions established international registries that allowed - and still allow today - the possibility of an easy extension of rights among contracting countries through a single application to the International Bureau. The most significant are the 1891 arrangement for international trademarks (currently ratified by 56 countries), the 1925 agreement on industrial design (60 countries), and the 1970 PCT (146 countries). Although national states retain the final decision and can reasonably oppose certain concessions in their territories, these agreements have become a significant shortcut for defending IPRs, especially for multinational corporations, which can cheaply and easily "buy time" and generate "right expectations" in many countries through a simple international application. In addition, regional-level convergence in IPR issues soared in distinct world areas, ${ }^{38}$ as occurred in the European Union through the means of the European patent (1973), the Community trademark (1994), the Community industrial design (2002), the current and still controversial European Unitary patent (2012), and several copyright directives such as those affecting computer programs (1991) or copyright duration (1993). ${ }^{39}$

Nevertheless, the most significant and recent step toward IPR globalization has probably been the creation of the World Trade Organization (WTO) in 1994, whereby an Agreement on Trade-Related Aspects of Intellectual Property Rights (commonly known as the TRIPS) was developed. ${ }^{40}$ The TRIPS became crucial in order to defend developed countries' commercial interests against illegal copying of technology, industrial design, and distinctive signs, especially in small and medium underdeveloped economies that could face severe trade sanctions. Even big economies, such as China, had problems entering the WTO as the 
prevalence of fake activities became a particular barrier to trade with certain countries, such as the United States, during the 1990 s. $^{41}$

As international treaties, arrangements, and agreements on IPRs spread, national laws also evolved and adapted to comply with the new rules. In that long-term process, corporations certainly influenced IPR institutions at both domestic and international levels in their eagerness to expand the ownership and control of their intangible assets. For some critical scholars, such internationalization was not neutral and strongly enhanced the rights of IPR holders to transform them into "tools of power and control over technology and people." "2 For the mainstream, strong international IPRs are just a basic requirement for guaranteeing legal certainty in the new "knowledge economy" and promoting both innovation and technology transfer. ${ }^{43}$ In any case, FDI and IPRs have undoubtedly co-evolved in the same direction: that of globalization.

\section{Foreign investment in Spain before WWII}

Foreign influence has been a strong and positive determinant of Spain's economic and business modernization since its early stages. The available evidence demonstrates that Spain, as a lessdeveloped economy, was a major recipient of foreign capital as well as a net importer of technology throughout the long nineteenth century (c. 1800-1936). ${ }^{44}$ However, the FDI data in Spain lack continuity and reliability for many periods. Even though some authors have tried to calculate those flows in the long-run, ${ }^{45}$ we prefer to use another proxy for FDI, such as the number of foreign businesses operating in Spain between 1820 and 1914 and the global capital (in million pesetas) invested in Spain by sectors and countries between 1851 and WWI. In our opinion, such data, although not perfect, are more reliable for approaching long-term inward FDI as they were collected from outstanding information existing in significant European and American archives. ${ }^{46}$ 
Table 1. Foreign corporations operating in Spain (1820-1914) and their capital in million pesetas (1851-1914)

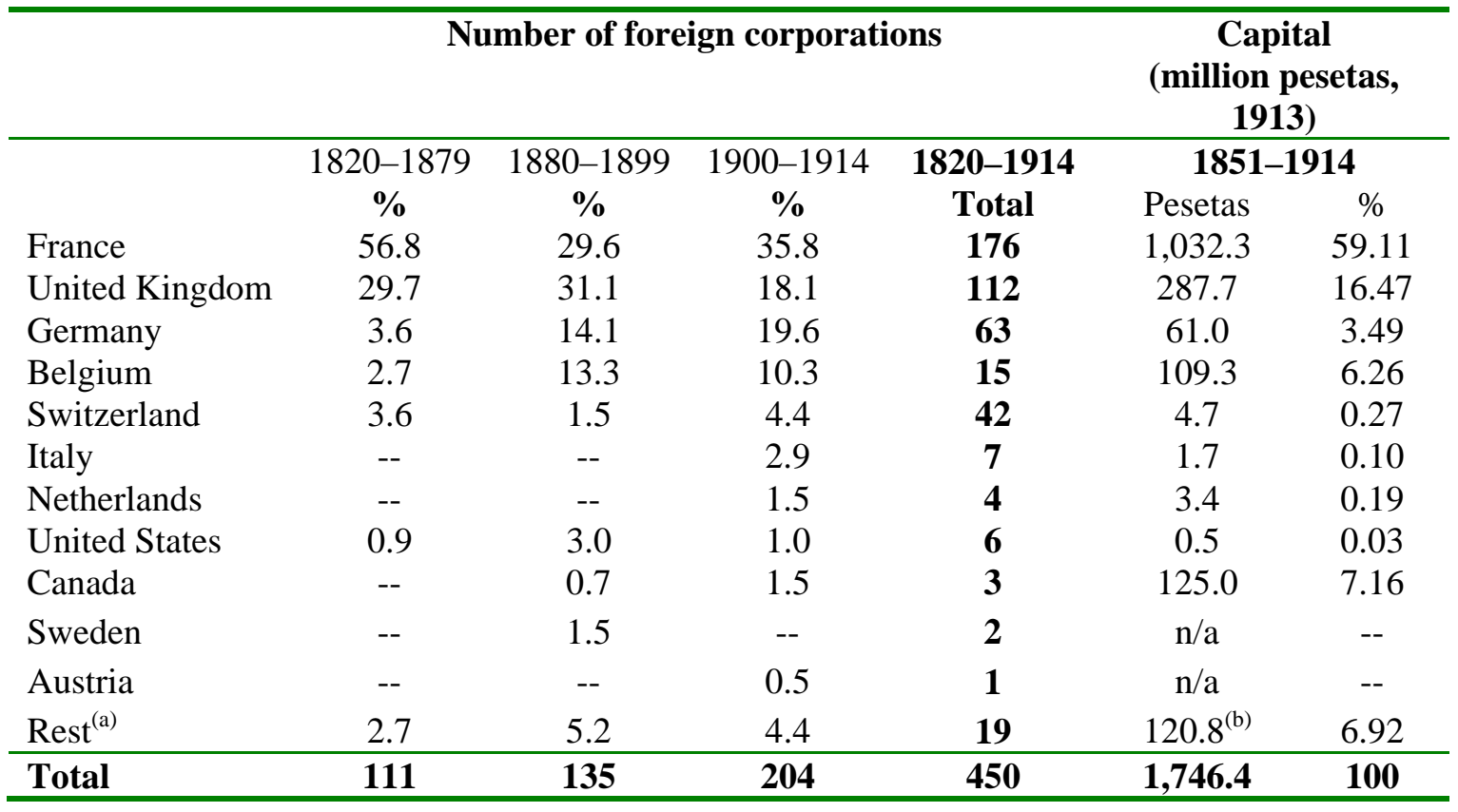

(a) "Rest" includes firms from Norway, Argentina, Czechoslovakia, Denmark, and Mexico. In the case of capital, "Rest" cannot be disaggregated; thus, we do not know the exact amount invested by Swedish and Austrian firms.

Source: T. Tortella, A Guide to Sources, Tables 1 and 2

As Table 1 shows, four main investors in the Spanish economy stood out before WWI: France, the United Kingdom, Germany, and Belgium. Among them, French capital and institutions were the most prominent influence in the Spanish economy. ${ }^{47}$ In reality, France's hegemonic position was not only a consequence of geographical proximity (location), but also of institutional receptivity. French investment focused principally on railways and mining, as well as on certain public utilities, activities that required a friendly legal framework, industryoriented financial institutions, and adequate human resources in order to increase the receptivity of the county. The significant advantage of French investors operating in Spain based on investment banks developed for sustaining international businesses, a process that became highly visible during the belle époque through the Rothschild and Péreire families. ${ }^{48}$ Less prominent enterprising families also played a main role in nineteenth-century Spain. For instance, families such as the Cros, the Lebon, the Mahou, the Delclaux, and the Rivière achieved dominant positions in the Spanish chemicals, gas, beer, glass, and metal industries. ${ }^{49}$ With the assistance of Spanish partners and the capability to integrate quickly into their new environment, these firms demonstrated a remarkable ability to survive.

Even though French investors had to face the country’s chronic political instability, a narrower than expected domestic market, and mounting protectionism, the French investment 
pattern has proven strikingly persistent. The fact that 14 of the 25 largest Spanish industrial firms in 1917 were under French control gives us an idea of how important French capital and know-how had become on the eve of WWI. ${ }^{50}$ Among such companies, we find economic interests in railways (Compañía de los Caminos del Hierro del Norte de España, Compañía de los Ferrocarriles de Madrid a Zaragoza y Alicante), public utilities (Catalana de Gas y Electricidad, Gas Lebon), and metallurgy (Sociedad Minera y Metalúrgica de Peñarroya). ${ }^{51}$ Unsurprisingly, French investment left a strong imprint on Spanish institutions, business organization, and managerial practices, including IPRs. They influenced the design of laws that regulated foreign investment in Spain, above all in railways (1855), banking (1856), and mining (1859). ${ }^{52}$ Similarly, the modern Spanish patent system was decreed under Joseph Bonaparte’s French Government in 1811, and the subsequent Spanish laws of 1820 and 1826, in force until 1878, retained the original French influence. ${ }^{53}$ Spain and France also followed similar patterns of pre-modern local mark protection and the 1850 Spanish and 1857 French trademark laws were the first in Europe to grant them on a national scale. ${ }^{54}$

The British imprint was comparatively weaker and delayed to the last quarter of the nineteenth century (Table 1). Although British companies also showed an interest in Spain, their subsidiaries seldom established strong links with the existing entrepreneurial structure. This pattern became evident in mining. In other industries in which British capital and know-how were relevant, such as alcoholic beverages, textiles, metal, shipbuilding, and hotels, their competitors were quick to adopt British business organization and practices. British heritage was particularly intense in the south-west (Jerez, Huelva) and the urban and industrialized areas of the North coast (Bilbao). The largest British companies with Spanish subsidiaries included Tharsis Sulphur \& Copper, Rio Tinto, Vickers, and Coats. In some joint ventures, local partners also played a crucial role. Basque and Catalan financial groups and industrial dynasties, such as Urquijo, Ybarra, Gandarias, and Portabella, were the most relevant, as well as King Alfonso XIII, who attracted many British investors to his businesses. ${ }^{55}$

The third major investor in Spain was Belgium. The pattern of Belgian capitalists had two faces (Table 2). Since the mid-nineteenth century to the 1890s, they focused on railways (Ferrocarril Central de Aragón, Ferrocarriles del Este de España), banking (Banco Comercial Español), and mining (Real Compañía Asturiana de Minas), often associated with French and British interests. ${ }^{56}$ When the Germans increased their investments in Spain, the Belgians were frequently linked with their neighbors. This was the case for trams (Tranvías Eléctricos de Murcia, Tranvías del Este de Madrid, Tranvías de Galicia), electricity (Sociedad Española de Lámparas Eléctricas “Z”, Société Financière de Transport et d'entreprises Industrielles SOFINA), chemicals (Solvay), and even ventures like the Palace Hotel in Madrid. This switch could explain the importance of Belgian capital in Spain until WWI and the apparent withdrawal in the interwar period. ${ }^{57}$ 
The development of the first globalization provoked large losses for French and British investors, who had to face increasing competition from German and US firms. These newcomers drove the second industrialization wave on a scientific and financial basis substantially different from the first, which would require deepening into intangible asset protection and ownership. Despite the Spanish mounting protectionism since the 1880s, foreign capital found no barriers before the Great War. In fact, Spain became one of the scenarios in which the great powers fought to keep their political and economic hegemony. Protectionism and economic nationalism had a strong influence on the dealings of foreign firms in Spain, actually encouraging direct investment, joint ventures, and some friendly takeovers of foreign assets by national companies.

The trends at the end of the nineteenth century continued during the interwar period. Officially, French capital kept its historical leadership. ${ }^{58}$ Nevertheless, it was no longer focused exclusively on railways, mining, and utilities, but also on more cutting-edge activities. This was the case of Air Liquide, Rhône Poulenc, Sociedad Española del Oxígeno, Sociedad Ibérica de Construcciones Eléctricas, Péchiney, and Saint Gobain. Despite the change of path, French FDI was threatened by strong German investments in sectors such as the electrical industry (Siemens, AEG, Telefunken, and Osram), chemical and pharmaceutical industries (IG Farben, ${ }^{59}$ Continental, Schering, Merck, Boehringer, La Minera/Fodina, Abelló Oxígeno Linde), insurance (Plus Ultra, Deutsche Lloyd), and trams, often associated with Belgians, as mentioned previously. 
Table 2. Main direct investors in Spain by country and sector, 1851-1914 (in millions of pesetas, 1913)

\begin{tabular}{|c|c|c|c|c|c|c|c|c|c|c|c|}
\hline Sector & France & UK & Canada & Belgium & Germany & Switzerland & Netherlands & Italy & US & Sweden & Austria \\
\hline & $\%$ & $\%$ & $\%$ & $\%$ & $\%$ & $\%$ & $\%$ & $\%$ & $\%$ & $\%$ & $\%$ \\
\hline Transport $^{(a)}$ & 44.0 & 30.9 & -- & 57.0 & 5.1 & 22.2 & -- & -- & -- & -- & -- \\
\hline Services ${ }^{(b)}$ & 38.3 & 5.8 & -- & 1.7 & 10.6 & 1.7 & 2.1 & 0.6 & 11.3 & $\mathrm{n} / \mathrm{a}^{(\mathrm{e})}$ & -- \\
\hline Public utilities $^{(\mathrm{d})}$ & 1.0 & 1.0 & 100 & -- & 30.4 & 25.3 & 8.9 & -- & 26.4 & $\mathrm{n} / \mathrm{a}^{(\mathrm{e})}$ & $\mathrm{n} / \mathrm{a}^{(\mathrm{e})}$ \\
\hline Chemicals & 2.8 & 0.4 & -- & 6.6 & 10.1 & 21.1 & -- & -- & -- & -- & -- \\
\hline Construction & 2.4 & 1.0 & -- & -- & 0.4 & -- & -- & -- & -- & -- & -- \\
\hline Food, beverages, and tobacco & 2.1 & 0.2 & -- & -- & 2.5 & 13.3 & -- & -- & -- & -- & -- \\
\hline Paper & 0.1 & -- & -- & -- & 0.1 & -- & -- & -- & -- & -- & -- \\
\hline Textiles & -- & 2.4 & -- & 1.4 & 1.6 & -- & -- & -- & -- & -- & -- \\
\hline Communication & -- & 2.3 & -- & 0.4 & -- & -- & -- & 89.3 & -- & -- & -- \\
\hline Glass & 0.4 & -- & -- & 0.9 & -- & -- & -- & 7.1 & -- & -- & -- \\
\hline Machinery and equipment & -- & 1.0 & -- & -- & 1.9 & 0.4 & -- & -- & 62.3 & -- & -- \\
\hline Others & 0.70 & 0.1 & -- & 4.6 & 0.3 & 0.2 & -- & 3.0 & -- & -- & -- \\
\hline Total (pesetas) & $1,032.3$ & 287.7 & 125.0 & 109.3 & 61.0 & 4.7 & 3.4 & 1.7 & 0.5 & $\mathrm{n} / \mathrm{a}^{(\mathrm{e})}$ & $\mathrm{n} / \mathrm{a}^{(\mathrm{e})}$ \\
\hline
\end{tabular}

(a) Includes shipbuilding and automobiles;

(b) Includes banking and finance, general trade, and commission agents;

(c) Includes iron and steel;

(d) Includes electricity, gas, and lighting.

(e) The amount of capital is not available, but we found two Sweden firms in services and one (as well as one Austrian firm) in public utilities.

Source: T. Tortella, A Guide to Sources, Table 3. 
Thus, despite the official "preponderance,” French businesses in interwar Spain began to show weaknesses. French firms lost power within the international cartels that ruled most of the science-based industries in which Spanish partners therefore had a passive role. This slippage was a source of concern for the French authorities, which became worried on the rise of competitors' influence in Spain. This sentence by André Barthe, reporter of the French Chamber of Commerce in Madrid at that time, summarizes the mood of French capitalists:

Malgré les avertissements, les jouets sont allemands, les machines sont américaines et les objets de la mer sont anglais ... Il ne reste pas grand-chose à obtenir, mais ce qu'il reste devra être combattu [...]. ${ }^{60}$

Unsurprisingly, the take-off of the SIR in Spain had a strong German imprint. As French firms, German companies held close ties with industrial banks, particularly the Deutsche Bank. Its Spanish subsidiary, the Banco Alemán Transatlántico, played an important role in the strategy and operations of the largest German firms in pre-war Spain. Although at this point most of those firms were mainly commercial, the pattern of German investment was strongly industrial, linked to the new science-based sectors and sustained by patents and partnerships with domestic industrial firms. The German influence especially increased between the Spanish Civil War and the end of WWII. ${ }^{61}$

The US investments in Spain were not outstanding before WWI. Although Tortella's data in Table 1 do not systematically collect all US ventures, recent studies focusing entirely on the issue found no more than 15 North American firms operating in Spain before 1914, mainly in food industries, light machinery, chemicals, and services (banking and insurance). ${ }^{62}$ Even though other evidence also reveals early US investments cloaked in joint ventures with Spanish capitalists or third foreign firms, ${ }^{63}$ we can conclude that the North American direct presence was scarce. Notwithstanding, during the interwar period, US investments began to increase in Spain, reaching 72.2 million current US dollars in $1929 .{ }^{64}$ Eventually, during the 1950s and mainly from the 1960s onwards, US MNEs joined the traditional French, German, and British interest in the Spanish economy, spreading significant investments throughout distinct economic sectors. ${ }^{65}$ However, France and Germany would gradually recover their traditional prominence in the Spanish economy, above all after Spain's entry to the European Union in 1986, which was strongly supported by these two countries. In fact, France and Germany were the partners that benefited most from the new Spanish economic framework within the Union. ${ }^{66}$ 


\section{Foreign intellectual property in Spain before WWII}

Industrialization processes and globalization were phenomena linked with capital formation. During the nineteenth and twentieth centuries, the investments for generating and expanding such capital goods were increasingly related to the creation or discovery of new information, a production with serious appropriation problems. ${ }^{67}$ The aforementioned development of national and international IPRs - patents, trademarks, industrial design, or copyrights - responded to the necessity of safeguarding such information embedded in new inventions, designs, and knowledge. Thus, from the beginning, foreign investors, capitalists, inventors, and firms had to manage and deal with distinct IPR regimes, from countries at different development stages, progressively connected by international agreements. It is reasonable to think that the two issues, FDI and IPRs, were closely related and that complementary strategies for investment and intellectual protection existed.

As we have shown, Spain was the recipient of significant FDI from the most developed European economies throughout the nineteenth century and the first third of the twentieth, with gradual presence of North American investments from the 1880s. From 1820 to 1826, Spain definitively established a basic patent system ${ }^{68}$ that was completed with the 1834 copyright act, ${ }^{69}$ the 1850 trademark law, ${ }^{70}$ and finally the 1878 patent law. ${ }^{71}$ The industrial property laws of 1902 and 1929 jointly ruled inventions and distinctive signs and extended the protection to new modalities, such as utility models and industrial design (drawings and models). ${ }^{72}$ This IPR system remained in force in Spain until 1986, upon joining the European Union. The new laws of 1986 (patents), 1988 and 2001 (trademarks), 2003 (industrial design), and 1987 and 1996 (copyright) ${ }^{73}$ updated the IPR framework to the European standards.

Previous works have described the pre-1986 Spanish IPR system as "hybrid.” As the location and receptivity theories predict for less-developed countries with few comparative advantages in international markets (which certainly includes markets for innovation), the Spanish IPR laws brought just enough protection for fitting basic international standards and for allowing foreigners to register intangible assets, but always maintained harsh domestic protection by the means of compulsory working clauses (for patents and trademarks), patents of introduction (which allowed the registering of others' inventions if they were not implemented within the national territory), or discriminatory measures against foreign trademark owners, who, before 1883, should open an industrial establishment within Spain. ${ }^{74}$ Those domestic restrictions on intangible ownership do not seem to have stopped foreign patenting and trademarking during the period studied. On contrary, as occurred with FDI in the Spanish economy, foreign IPRs constantly increased.

On the other hand, such restrictions were not very different from what originally occurred in many other countries in their first development stages. The United States, for instance, discriminated against foreigner patentees until 1861 and did not recognize foreign 
copyright at least until $1891 .^{75}$ Similar measures against foreigners existed in the Japanese patent law from 1871 to $1899,{ }^{76}$ and many countries promoted "patents of introduction or importation" to encourage the adoption of foreign technologies without respecting original foreign patents during the nineteenth century, ${ }^{77}$ or, as in France between 1844 and 1883, considered that a first patent abroad destroyed the novelty requisite for a domestic patent. ${ }^{78}$ In early stages, trademarks were also restricted to domestic (or foreign resident) manufacturers everywhere.

In Spain, except for the aforementioned trademark supposition (and without any restrictions for signing countries after the 1883 Convention of Paris), foreign applications were fully accepted from the beginning, although other domestic protection measures such as patents of introduction or compulsory working clauses remained active until 1986. Thus, from 1820 for patents and from 1850 for trademarks, a complete national register for both domestic and foreign industrial property is available. Thanks to an outstanding agreement between the Spanish patent and trademark office (OEPM) and the Universidad Autónoma de Madrid (UAM), the first 150,000 patent files (1820-1939) and 36,000 trademark files (1850-1916) have been analyzed and catalogued in detail by our research group during the last 12 years. ${ }^{79}$

Figure 1 disaggregates the patent and trademark applications in Spain by place of residence and reveals two distinct phases regarding foreign participation. Before the 1870s, domestic applicants exceeded non-residents for taking both patents and especially trademarks, among which there were very few foreigners. During this period, the IPR system was just being established and annual grants were scarce, corresponding to a phase of political instability, especially before 1845, and of the first modern economic growth until 1864-68 linked to railways, banking, and certain industrial activities highly concentrated in Catalonia, Madrid, the Basque Country, and some other areas of the North, Andalusia, and the Mediterranean coast. ${ }^{80}$ Thus, industrial foreign investment was still hard to find before 1845, and it was dominated by the French proximity and influence until the 1880s (see Table 1), which totally coincides with the French supremacy in taking patents and trademarks in Spain before that decade (see Tables 3 and 4). 
Figure 1: Patents and trademarks in Spain by applicant's residence, 1820-1939

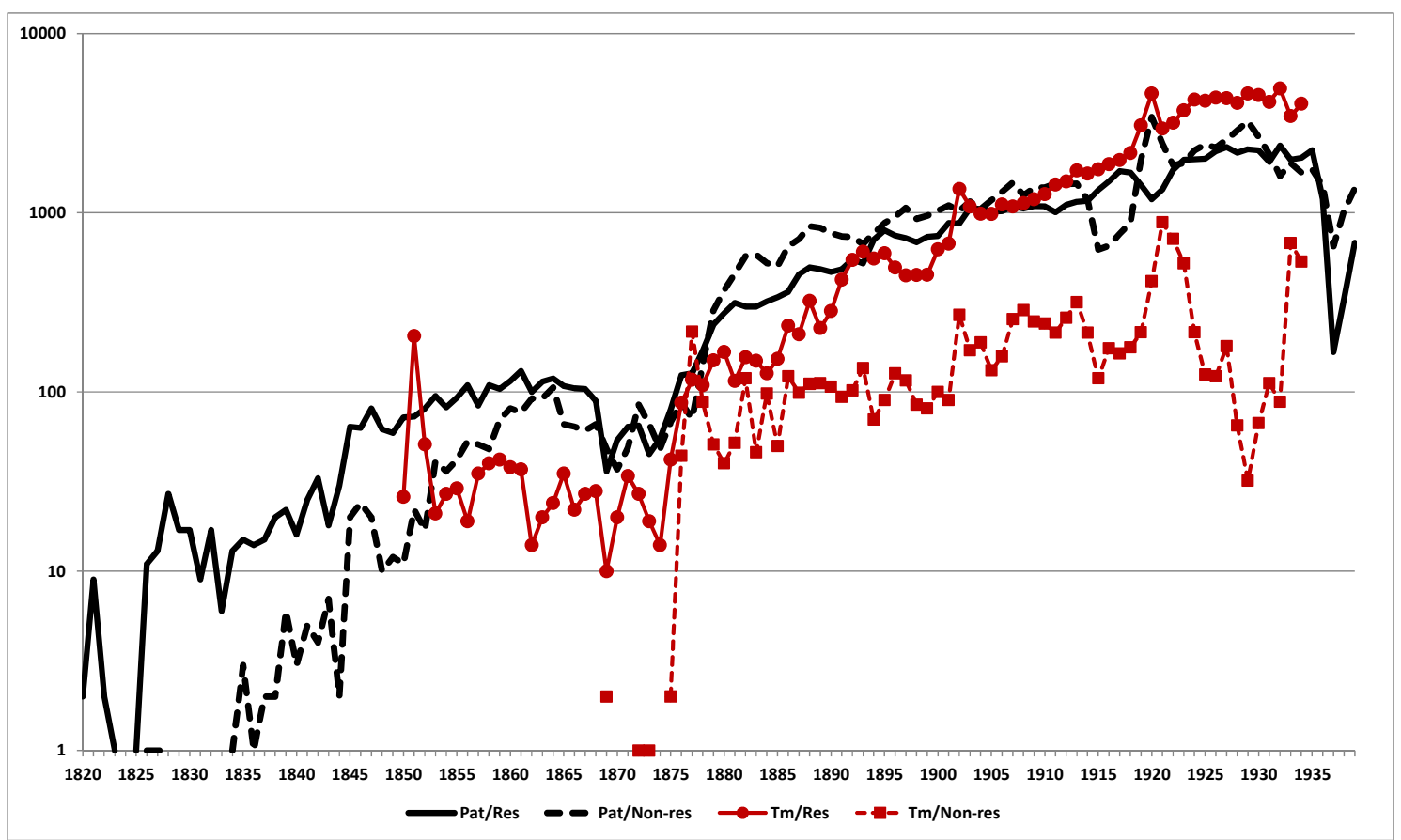

Sources: Archivo Histórico Nacional and Gaceta de Madrid for patents from 1820 to 1826. Original files at the OEPM's archive for patents from 1826 to 1939 and trademarks from 1850 to 1916. WIPO official statistics for trademarks from 1917 to 1934.

As Figure 1 demonstrates, from the end of the 1870s to 1939 a new phase in industrial property arose. Patents and trademarks constantly grew in Spain during that period as well as foreign interest in applying for them. Besides Spanish institutional and economic improvements, technological shifts linked to the new Industrial Revolution, the appearance of new goods and selling strategies, increasing international competition among North Atlantic economies, and new corporate strategies for managing intangible assets outside the national borders also explain the outstanding increases in non-resident patents and trademarks. From 1880, foreign patentees always outstripped domestic ones throughout the entire period analyzed, with WWI being the only exception. In fact, a significant percentage of resident patents were taken by Spaniards as "patents of introduction" for alien technologies, or even by foreign residents living in Spain, which makes Spanish technological dependence higher yet. ${ }^{81}$ The number of foreign trademark owners also grew during this period, first after bilateral agreements for mark protection between Spain and France (1876), the United Kingdom (1876), and the United States (1882), and second after signing the 1883 international agreement on industrial property $;{ }^{82}$ however, contrary to patents, domestic trademarks always outnumbered foreign ones. As trademarks protect product distribution within a domestic market, it seems reasonable that resident industrialists, manufacturers, and businessmen dominated the national scenarios. Similarly, protectionism and especially the impact of WWI and the following commercial contraction during the interwar 
period were matters that negatively influenced marks' international spread, as can be easily checked in Figure 1.

Table 3. Foreign patents in Spain by applicant's country of residence, 1820-1939

\begin{tabular}{|c|c|c|c|c|c|}
\hline & $\begin{array}{c}1820-1879 \\
\%\end{array}$ & $\begin{array}{c}1880-1899 \\
\%\end{array}$ & $\begin{array}{c}1900-1919 \\
\%\end{array}$ & $\begin{array}{c}1920-1939 \\
\%\end{array}$ & $\begin{array}{c}1820-1939 \\
\%\end{array}$ \\
\hline France & 58.6 & 29.5 & 23.9 & 20.3 & 24.0 \\
\hline Germany & 4.8 & 17.9 & 22.1 & 26.5 & 23.1 \\
\hline United Kingdom & 19.1 & 17.0 & 15.1 & 12.7 & 14.3 \\
\hline United States & 8.1 & 17.5 & 13.8 & 11.9 & 13.3 \\
\hline Switzerland & 1.3 & 1.8 & 3.8 & 6.4 & 4.7 \\
\hline Italy & 2.1 & 2.3 & 4.5 & 5.5 & 4.5 \\
\hline Belgium & 2.6 & 3.9 & 3.6 & 2.6 & 3.1 \\
\hline Netherlands & 0.4 & 0.6 & 1.0 & 3.4 & 2.1 \\
\hline Austria & 0.8 & 2.1 & 1.8 & 1.8 & 1.8 \\
\hline Sweden & 0.2 & 1.0 & 1.7 & 1.8 & 1.6 \\
\hline Canada & -- & 0.5 & 0.6 & 0.3 & 0.4 \\
\hline $\operatorname{Rest}^{(a)}$ & 1.9 & 5.8 & 8.1 & 6.9 & 6.9 \\
\hline TOTAL patents & 2,209 & 14,485 & 23,727 & 41,309 & 81,730 \\
\hline
\end{tabular}

(a) 69 countries with less than $1 \%$ of patents each.

Source: See Figure 1

Table 4. Foreign trademarks in Spain by applicant's country of residence, 1850-1916

\begin{tabular}{|c|c|c|c|c|}
\hline & $\begin{array}{c}1850-1879 \\
\%\end{array}$ & $\begin{array}{c}1880-1899 \\
\%\end{array}$ & $\begin{array}{c}1900-1916 \\
\%\end{array}$ & $\begin{array}{c}1850-1916 \\
\%\end{array}$ \\
\hline United Kingdom & 11.3 & 31.0 & 26.6 & 26.9 \\
\hline Germany & 1.0 & 16.1 & 35.4 & 26.7 \\
\hline France & 84.2 & 34.5 & 10.4 & 23.5 \\
\hline United States & 1.0 & 6.6 & 16.5 & 12.2 \\
\hline Austria & 1.2 & 2.5 & 1.3 & 1.7 \\
\hline Switzerland & 0.7 & 3.5 & 0.3 & 1.4 \\
\hline Sweden & -- & 0.6 & 1.2 & 0.9 \\
\hline Italy & -- & 0.6 & 1.1 & 0.9 \\
\hline Belgium & 0.5 & 1.5 & 0.5 & 0.8 \\
\hline Netherlands & -- & 0.7 & 0.3 & 0.4 \\
\hline Canada & -- & 0.1 & 0.2 & 0.2 \\
\hline $\operatorname{Rest}^{(\mathrm{a})}$ & -- & 2.3 & 6.2 & 4.4 \\
\hline TOTAL trademarks & 406 & 1,857 & 3,436 & 5,699 \\
\hline
\end{tabular}

(a) 24 countries with less than $0.4 \%$ of trademarks. We show in the table neither Cuba $(0.9 \%)$, nor Argentina (0.8\%), nor Denmark (0.4\%)

Source: See Figure 1 
Unsurprisingly, the majority of foreign patent and trademark applications came from the same group of developed countries that invested in the Spanish economy throughout the long nineteenth century (Tables 1, 3, and 4). Three countries - France, Germany, and the United Kingdom - added up to 73\% of firms and 79\% of capital invested before WWI and obtained almost $62 \%$ of patents and $77 \%$ of trademarks applied by non-residents in Spain until WWII. Thus, as the main foreign investors, they were also the main users of the Spanish IPR system: first led by the French, who completely dominated the scenario before 1880 , followed by the British, who maintained their participation among patents during the whole period studied while increasing their trademark applications after 1880, and, finally, by the Germans, who progressively intensified their presence in the whole IPR system even more than the investment proxies showed.

Therefore, the industrial property data also indicate that, although being the principal investor, France gradually lost ground and influence in Spain after the SIR, while Germany gained them. Patent series clearly confirm the scientific and technological basis for German expansion, not only prior to WWI but during the 1920s and 1930s, when Germany turned into the most significant foreign patent owner in Spain (Table 3). Leader in several new knowledgeintensive industrial sectors, Germany also seemed to know how to penetrate foreign consumption markets while the first globalization process emerged, as the trademark proxy shows. Along with Germany, Britain also used distinctive signs profusely from 1880 onwards, while France, the leader in trademarking during the first three-quarters of the nineteenth century, decreased until WWI.

As we saw in Section 2, the US investments in Spain were anecdotal before WWI and, although increasing, did not especially stand out during the interwar period either. However, the United States had progressively incremented its ventures in Europe during the last quarter of the nineteenth century. US early significant investments had reached the most developed European countries through the expansion of the first American corporations, such as several of Edison's firms for electric lighting established in France, Germany, and the United Kingdom during the 1880s, ${ }^{83}$ Babcock Wilcox subsidiaries in England and Germany during the 1890 s, ${ }^{84}$ and the American Radiator Company in many countries during the 1900s. ${ }^{85}$ Before WWI, Europe had received roughly $20 \%$ of US direct investment, especially the United Kingdom. ${ }^{86}$ Nevertheless, its role as an international financial power would become a critical issue only after the Great War and, especially, with the FDI executed after WWII, as it is commonly known. ${ }^{87}$

At any rate, a strong component of the US international expansion was, and still is, based on added value provided by scientific and technological knowledge. As was occurring in Germany, but on an even larger scale, US innovation processes and policies would soon change the entire economy and entrepreneurial context. Thus, IPR management turned into a critical question for international US interests from the beginning. As far as Europe became a business 
target, US companies began to take thousands of patents and trademarks. Whether or not Spain was the recipient of substantial US investments before WWII, the American IPR strategies in Europe had to include it. Good proof of that is the increasing presence of US intangible assets in Spain throughout the period studied (around 13\% of both foreign patent and foreign trademark applications), which achieves the fourth position among foreign IPR owners.

On the other hand, countries such as Canada and even Belgium, which were apparently more relevant in direct investment before WWI, were less represented in the Spanish IPR system. As we mentioned previously, Belgian investments in Spain were centered on railways and mining, and Canadian ventures were highly concentrated in an electrical entrepreneurial conglomerate (Barcelona Traction) during the period studied. ${ }^{88}$ These sectors required significant amounts of fixed capital, leading in practice to natural monopolies, and therefore might make IPR protection less crucial for some firms, especially in mining, metals, and transport, as some literature focusing on FDI and IPRs has shown. ${ }^{89}$ Finally, a group of five countries formed by Switzerland, Italy, the Netherlands, Austria, and Sweden, which progressively began to compete internationally from 1880 onwards, conducted slight investments in Spain and took patents and trademarks in a similar proportion. 
Table 5. Patents in Spain from the most significant foreign countries grouped by economic sector, 1820-1939

\begin{tabular}{|c|c|c|c|c|c|c|c|c|c|c|c|}
\hline 1820-1939 & $\begin{array}{c}\text { France } \\
\%\end{array}$ & $\begin{array}{c}\text { Germany } \\
\%\end{array}$ & $\begin{array}{c}\text { U. Kingdom } \\
\%\end{array}$ & $\begin{array}{c}\text { U. States } \\
\%\end{array}$ & $\begin{array}{c}\text { Switzerland } \\
\%\end{array}$ & $\begin{array}{c}\text { Italy } \\
\%\end{array}$ & $\begin{array}{l}\text { Belgium } \\
\%\end{array}$ & $\begin{array}{c}\text { Netherlands } \\
\%\end{array}$ & $\begin{array}{c}\text { Austria } \\
\%\end{array}$ & $\begin{array}{c}\text { Sweden } \\
\%\end{array}$ & $\begin{array}{c}\text { Canada } \\
\%\end{array}$ \\
\hline Machinery and equipment & 27.2 & 23.1 & 26.3 & 23.3 & 27.3 & 24.4 & 25.8 & 16.5 & 18.5 & 36.8 & 23.5 \\
\hline Services & 10.4 & 11.8 & 7.6 & 8.9 & 10.2 & 11.6 & 8.4 & 6.6 & 14.0 & 8.2 & 12.3 \\
\hline Chemicals & 7.9 & 10.7 & 6.5 & 7.2 & 11.0 & 7.2 & 8.8 & 9.9 & 9.4 & 5.7 & 4.6 \\
\hline Electricity & 6.9 & 8.1 & 6.3 & 7.3 & 9.9 & 7.0 & 7.0 & 30.1 & 7.8 & 6.7 & 3.7 \\
\hline Textile & 7.7 & 7.7 & 8.4 & 8.0 & 8.7 & 6.8 & 6.0 & 4.0 & 7.9 & 3.3 & 5.6 \\
\hline Food, beverages, and tobacco & 7.1 & 5.1 & 4.6 & 9.0 & 7.1 & 6.6 & 6.9 & 4.7 & 8.1 & 7.4 & 7.4 \\
\hline Basic metals & 4.5 & 5.7 & 7.1 & 6.5 & 3.4 & 3.6 & 4.8 & 2.6 & 5.6 & 6.5 & 8.6 \\
\hline Non-rail transport & 5.4 & 2.7 & 5.3 & 4.1 & 4.0 & 6.4 & 4.5 & 2.4 & 2.4 & 1.3 & 6.5 \\
\hline Arms industry & 3.0 & 4.9 & 6.2 & 2.5 & 2.5 & 4.3 & 5.2 & 1.4 & 5.1 & 4.1 & 1.2 \\
\hline Railway & 3.7 & 2.8 & 2.9 & 3.9 & 3.5 & 3.9 & 6.0 & 0.9 & 3.6 & 2.7 & 2.5 \\
\hline Construction & 3.3 & 3.7 & 2.9 & 2.6 & 4.0 & 3.7 & 5.0 & 2.8 & 5.5 & 2.8 & 2.5 \\
\hline Paper and graphic arts & 2.3 & 2.9 & 2.9 & 3.6 & 2.4 & 2.5 & 1.7 & 1.9 & 3.7 & 3.3 & 4.9 \\
\hline Communication & 1.8 & 2.0 & 3.4 & 3.7 & 0.7 & 1.8 & 1.5 & 4.2 & 1.1 & 2.9 & 1.5 \\
\hline Gas and lighting & 2.6 & 2.3 & 2.3 & 1.7 & 1.3 & 1.4 & 2.6 & 3.5 & 3.1 & 1.9 & 2.8 \\
\hline Mining and coal & 1.6 & 2.0 & 2.6 & 2.6 & 0.9 & 0.8 & 2.7 & 3.6 & 1.2 & 1.7 & 2.8 \\
\hline Sea transport and ports & 1.2 & 1.2 & 2.2 & 2.4 & 1.1 & 3.5 & 0.6 & 3.1 & 0.9 & 1.6 & 3.4 \\
\hline Agriculture and cattle farming & 1.7 & 1.4 & 0.7 & 1.2 & 1.0 & 2.0 & 1.0 & 0.6 & 0.9 & 1.2 & 1.5 \\
\hline Aeronautics & 0.9 & 1.4 & 1.0 & 0.8 & 0.3 & 1.9 & 0.5 & 1.2 & 0.2 & 0.4 & 0.6 \\
\hline Lumber industry & 0.9 & 0.7 & 0.8 & 0.8 & 0.5 & 0.6 & 1.0 & 0.2 & 1.0 & 1.4 & 4.0 \\
\hline TOTAL patents & 19,643 & 18,898 & 11,698 & 10,901 & 3,853 & 3,708 & 2,555 & 1,736 & 1,474 & 1,290 & 324 \\
\hline
\end{tabular}

Source: See Figure 1 
Table 6. Trademark designations of goods and services in Spain from the most significant foreign countries grouped by economic sector, $1850-1916$

\begin{tabular}{|c|c|c|c|c|c|c|c|c|c|c|c|}
\hline & $\begin{array}{c}\text { Germany } \\
\% \\
\end{array}$ & $\begin{array}{c}\text { U. Kingdom } \\
\% \\
\end{array}$ & $\begin{array}{c}\text { France } \\
\% \\
\end{array}$ & $\begin{array}{c}\text { U. States } \\
\%\end{array}$ & $\begin{array}{c}\text { Austria } \\
\%\end{array}$ & $\begin{array}{c}\text { Switzerland } \\
\% \\
\end{array}$ & $\begin{array}{c}\text { Sweden } \\
\% \\
\end{array}$ & $\begin{array}{c}\text { Italy } \\
\%\end{array}$ & $\begin{array}{c}\text { Belgium } \\
\%\end{array}$ & $\begin{array}{c}\text { Netherlands } \\
\% \\
\end{array}$ & $\begin{array}{c}\text { Canada } \\
\% \\
\end{array}$ \\
\hline Chemicals (consumption) & 36.6 & 31.3 & 33.1 & 38.4 & 27.5 & 10.2 & 7.2 & 36.2 & 22.4 & 16.0 & 53.8 \\
\hline Textiles & 11.2 & 18.2 & 17.2 & 10.4 & 3.7 & 24.1 & -- & 13.8 & 16.3 & -- & 7.7 \\
\hline Machinery and equipment ${ }^{(a)}$ & 17.0 & 11.7 & 6.5 & 19.0 & 22.9 & 5.6 & 41.0 & 1.7 & 10.2 & 4.0 & 7.7 \\
\hline Beverage & 2.9 & 7.5 & 20.7 & 0.4 & 0.9 & 2.8 & 1.2 & 29.3 & 14.3 & 24.0 & 15.4 \\
\hline Food & 5.0 & 8.2 & 6.0 & 5.3 & 1.8 & 23.1 & 1.2 & 8.6 & 16.3 & 44.0 & 15.4 \\
\hline Tobacco & 1.7 & 1.6 & 6.7 & 2.0 & 7.3 & 15.7 & 9.6 & -- & 2.0 & -- & -- \\
\hline Basic metals and mining & 6.8 & 6.6 & 2.7 & 3.9 & 22.9 & 8.3 & 24.1 & 10.3 & 2.0 & -- & -- \\
\hline Paper and graphic arts & 5.7 & 4.7 & 2.0 & 7.1 & 4.6 & 0.9 & -- & -- & -- & -- & -- \\
\hline Services & 6.4 & 2.9 & 3.1 & 4.9 & 3.7 & 6.5 & 2.4 & -- & -- & -- & -- \\
\hline Transport (vehicles) & 2.0 & 2.6 & 0.6 & 4.8 & 1.8 & 0.9 & 9.6 & -- & 4.1 & 4.0 & -- \\
\hline Construction $^{(b)}$ & 1.7 & 1.0 & 0.7 & 1.1 & 0.9 & -- & 1.2 & -- & 6.1 & -- & -- \\
\hline Agriculture and cattle farming & 0.9 & 2.4 & 0.4 & 0.3 & 1.8 & 0.9 & -- & -- & 2.0 & -- & -- \\
\hline Arms industry & 0.9 & 0.9 & 0.2 & 2.1 & -- & 0.9 & -- & -- & 4.1 & -- & -- \\
\hline Communication & -- & -- & -- & 0.1 & -- & -- & -- & -- & -- & -- & -- \\
\hline Sector unknown & 1.1 & 0.4 & 0.2 & 0.1 & -- & -- & 2.4 & -- & -- & 8.0 & -- \\
\hline TOTAL designations & 2,644 & 1,969 & 1,485 & 791 & 109 & 108 & 83 & 58 & 49 & 25 & 13 \\
\hline
\end{tabular}

\footnotetext{
(a) Including electricity and lighting.

(b) Including lumber.
} 
As Table 5 shows, patents from all the aforementioned countries were especially concentrated in heavy industries, such as those related to machinery and equipment, the chemical sector, or electricity, and to lesser extent basic metals, mining, or transport, as the specialized literature predicts. ${ }^{90}$ However, light industries, such as textiles, food, beverages, and tobacco, or the wide services sector, also attracted a significant proportion of foreign innovation activity. Whether or not there are industries that are more inclined to use IPRs than others, heavy industries had more scientific or technical complexity and required heavier investments, which matches well what we have already exposed in section 3 above. In fact, the FDI sectorial structure in the Spanish economy (Table 2) reveals a similar concentration in transport, mainly railways but also shipbuilding and others (France, the United Kingdom, and Belgium), mining and basic metals (the United Kingdom, Belgium, and Germany), the chemical industry (mostly from Germany but also from Belgium and Switzerland), electricity and public utilities (Canada and Germany), as well as distinct service activities (mainly France). Foreign ventures in "machinery and equipment," that is, in establishments for producing general machinery, engines, or drives for multi-purpose use (and not included in the previously mentioned sectors), were scarce. Although apparently this does not fit well with the concentration of patents in that sector (Table 5), there is no contradiction. The issue comes from the patent classification system, in so far as generic advances in multi-purpose machinery, for instance, steam engines, boilers, or certain mechanisms, were patented in a broad and neutral way, not usually claiming specific uses. While investments clearly pointed to specific sectors, multi-purpose patents must be classified as "machinery and equipment." 91

Trademark analysis offers complementary information on foreign intangible assets in Spain. The fact that a trademark could be designated for different products, which might be classified in distinct industries, led us to focus on such goods. Actually, we counted 5,444 trademarks registered in Spain from the 11 countries we are studying between 1850 and 1916: marks that were designated for 7,334 goods. ${ }^{92}$ Trademarks spread first through consumer industries that commercialized high-demand products linked to basic necessities, then among heavy sectors. ${ }^{93}$ Nonetheless, after 1880, capital industries were also able to design new durable goods, which progressively increased in demand as the population's average income rose. Table 6 shows these two tendencies regarding foreign trademarking concentration in Spain. The kind of product protected under foreign marks was strongly related to consumer chemical products (such as perfumery, cosmetics, pharmaceutical preparations, lubricants, matches, soaps, paints, varnishes, colorants, etc.), which reached between 30 and 38\% of German, French, British, and US trademarks. Textiles, food, beverages, and tobacco-related goods were also significantly focused on by foreign trademarking. Textile marks came chiefly from the United Kingdom and France. The latter was also the origin of drink trademarks (almost 21\% of French goods registered), as we expected. 
Contrary to what was usual among residents, ${ }^{94}$ there were also significant percentages of foreign trademarks in capital goods, such as machinery and equipment (including electricity and lighting) and metallic products, especially among US and German applicants (19 and 17\%, respectively), and also among British applicants (11.7\%). Again, this fits well with the aforementioned Spanish technological dependence on heavy sectors, which were targeted by the most advanced countries either for direct investment or for exporting and selling machinery. The rest of the countries shown in Table 6 registered just a few trademarks compared with the four main ones. Although it is also possible to analyze their fields of trademark specialization during the period studied (Switzerland in food and textiles; Austria and Sweden in machinery and metallic products; Italy in drinks, etc.), the lack of evidence calls for limiting further conclusions.

Therefore, although the investment, patent, and trademark sectorial classifications have particularities that could introduce some distortions - because it is not the same to classify the activity of a firm, a patent for a technology, or a trademark for a commercial product - and despite the fact that distinct industry trends towards IPR protection could exist, our findings support a remarkable macro-level connection between FDI and IPRs. France, Germany, and the United Kingdom were both main investors and owners of patents and trademarks. The United States was the fourth country taking industrial property in Spain, although it was part of a wider European approach prior to the post-WWs investment landing. The rest of the countries with any business venture in Spain before 1914 fully coincided with the patent and trademark data. In all the countries studied, the Spanish heavy sectors and more complex industries stood out as investment targets, as occurs with technologies protected and to certain extent even with trademarks, which used to be largely linked to consumer goods and light industries. Would it be possible to find other evidence to determine whether there actually were distinct IPR strategies among foreign inventors, entrepreneurs, and firms?

\section{Foreign intangible assets in Spain. What were patents and trademarks taken for?}

As we saw in the previous section, US patent and trademark activity in Spain seems to have been a consequence of a wider European strategy that preceded the strong FDI materializing after WWII. To what extent was this IPR policy successful? Although French firms and businessmen were outstanding investors in Spain throughout the whole nineteenth century, they progressively lost ground in industrial property acquisition compared with the increasing German interest in guaranteeing patents and trademarks in the Spanish market. Had this anything to do with the evolution of their business management style in Spain? Eventually, all this lead us to the most significant question: What were patents and trademarks really for in a lagging country on the European periphery? 
It was not easy for foreign IPR owners to overcome the "liability of foreignness." Although aliens were progressively treated as nationals, the obligation to demonstrate patent and trademark working within the country in order to keep the monopoly was difficult to beat in certain periods, ${ }^{96}$ which especially affected foreigners. As we have seen in Section 2, the United States always fought this kind of clause in international treaties, which fits well with our findings here regarding the US strategy for assuring IPRs that preceded major investments. US intellectual monopolies could be difficult to enforce without direct ventures in the country or licenses to third parties, which would decrease the patent and trademark value. In fact, nowadays, the TRIPS - strongly supported by the United States - and other major international agreements do not allow such compulsory working clauses and mandatory licenses, and if they do exist it is enough to demonstrate patent or trademark working in any WTO member country, which is actually the same.

IPR holders also had to pay annual fees to maintain their monopolies, which would be worthwhile only if there were superior revenues. Schankerman and Pakes ${ }^{97}$ pioneered this approximation through a simple model based on patent renewals for estimating their private value, using data from several countries between 1950 and 1976. Although the historical context undoubtedly must be taken into account, ${ }^{98}$ we think that renewal data are an interesting point to check both for patents and for trademarks. In the case of patents, compulsory working data and renewal fees can be combined to assess the monopoly value. The recipient was required to demonstrate that the patented object was implemented in Spain within one to three years (a usual requirement in less-industrialized or nationalistic economies); ${ }^{99}$ otherwise, the technology would pass into the public domain. Once the patentee had overcome the implementation requirements, subsequent progressive installments had to be paid until the end of the monopoly (usually 20 years). ${ }^{100}$ Trademark compulsory working was implicit in their duration, as they could be immediately challenged by other firms, businessmen, or agents if the marks were abandoned or not operating in the Spanish market (for one to five years depending on the law), ${ }^{101}$ even if the periodical installments were paid. 
Table 7. Patents in Spain from the most significant foreign countries by implementation and duration, 1820-1939

\begin{tabular}{|c|c|c|c|c|c|c|}
\hline & PATENTS $^{(a)}$ & $\begin{array}{c}\text { Implemented } \\
\%\end{array}$ & $\begin{array}{c}\text { Non- } \\
\text { Implemented } \\
\%\end{array}$ & $\begin{array}{c}\text { Implemented } \\
\text { \& Duration }>5 \mathrm{y} . \\
\%\end{array}$ & $\begin{array}{c}\text { Implemented } \\
\text { \& Duration }>10 \mathrm{y} \text {. } \\
\%\end{array}$ & $\begin{array}{c}\text { Implemented } \\
\text { \& Duration }>15 \mathrm{y} . \\
\%\end{array}$ \\
\hline United Kingdom & 11,070 & 28.2 & 71.8 & 16.3 & 6.8 & 2.8 \\
\hline Sweden & 1,194 & 27.1 & 72.9 & 15.0 & 5.9 & 2.4 \\
\hline Belgium & 2,452 & 25.4 & 74.6 & 11.9 & 4.8 & 1.9 \\
\hline Austria & 1,406 & 23.3 & 76.7 & 11.0 & 3.8 & 1.6 \\
\hline United States & 10,273 & 23.3 & 76.7 & 13.3 & 6.1 & 2.5 \\
\hline France & 18,729 & 22.1 & 77.9 & 12.7 & 5.0 & 1.8 \\
\hline Germany & 17,781 & 19.4 & 80.6 & 10.5 & 4.1 & 1.4 \\
\hline Italy & 3,526 & 17.7 & 82.3 & 9.8 & 4.2 & 1.7 \\
\hline Switzerland & 3,558 & 17.0 & 83.0 & 10.9 & 4.7 & 2.2 \\
\hline Canada & 318 & 16.0 & 84.0 & 6.6 & 2.2 & 1.3 \\
\hline Netherlands & 1,631 & 14.2 & 85.8 & 8.5 & 3.7 & 1.1 \\
\hline $\begin{array}{l}\text { PATENT } \\
\text { system }\end{array}$ & $145,681^{(\mathrm{a})}$ & 20.9 & 79.1 & 10.7 & 4.2 & 1.8 \\
\hline
\end{tabular}

(a) The values were calculated based on an average of $95.3 \%$ of patents. The remainder had no implementation data.

Source: See Figure 1 
Table 8. Trademarks in Spain from the most significant foreign countries by duration, 1850-1916

\begin{tabular}{|c|c|c|c|c|c|c|c|c|}
\hline & TRADEMARKS $^{(\mathrm{a})}$ & $\begin{array}{c}>5 \text { years } \\
\%\end{array}$ & $\begin{array}{c}>10 \text { years } \\
\%\end{array}$ & $\begin{array}{c}>20 \text { years } \\
\%\end{array}$ & $\begin{array}{c}>40 \text { years } \\
\%\end{array}$ & $\begin{array}{c}>80 \text { years } \\
\%\end{array}$ & $\begin{array}{c}\text { In force } \\
{ }^{(b)}\end{array}$ & $\begin{array}{c}\text { Average } \\
\text { duration } \\
\text { (in years) }\end{array}$ \\
\hline United States & 686 & 90.2 & 81.8 & 61.1 & 30.6 & 11.4 & 8.0 & 34 \\
\hline United Kingdom & 1,385 & 87.7 & 82.9 & 65.1 & 33.1 & 11.8 & 5.9 & 34 \\
\hline Canada & 9 & 88.9 & 55.6 & 55.6 & 22.2 & 22.2 & 22.2 & 31 \\
\hline Sweden & 51 & 84.3 & 72.5 & 56.9 & 25.5 & 9.8 & 7.8 & 30 \\
\hline Switzerland & 74 & 75.7 & 71.6 & 56.8 & 16.2 & 1.4 & 1.4 & 24 \\
\hline Germany & 1,474 & 84.2 & 72.3 & 45.3 & 13.6 & 4.4 & 3.1 & 23 \\
\hline Italy & 47 & 74.5 & 55.3 & 40.4 & 12.8 & 8.5 & 4.3 & 21 \\
\hline Austria & 93 & 82.8 & 78.5 & 32.3 & 4.3 & 1.1 & 1.1 & 19 \\
\hline Netherlands & 23 & 69.6 & 52.2 & 43.5 & 8.7 & 4.3 & 4.3 & 18 \\
\hline France & 1,275 & 82.7 & 77.0 & 53.0 & 3.1 & 0.8 & 0.2 & 18 \\
\hline Belgium & 45 & 77.8 & 66.7 & 46.7 & 2.2 & -- & -- & 16 \\
\hline TRADEMARK system & $33,478^{(a)}$ & 69,7 & 55,3 & 35,6 & 11,6 & 4,1 & 2.4 & 19 \\
\hline
\end{tabular}

(a) The values were calculated based on an average of $95.2 \%$ of trademarks. Although expired, the remainder had no expiration date.

(b) Trademarks still in force during the period 2000-2010, when the database was progressively collected.

Source: See Figure 1 
Tables 7 and 8 show the foreign IPR duration in the periods studied. In the case of the patent system, an average of $79 \%$ of the grants did not pass compulsory working clauses and therefore theoretically expired before the fourth year. Furthermore, if we check the implemented patent duration, only $10.7 \%$ lasted between 6 and 10 years, 4.2\% between 11 and 15 years, and just 1.8 between 16 and 20 years. Notwithstanding, there were significant differences among countries, as can be seen in Table 7. If we suppose that longer monopoly duration reveals greater value of the patented technologies and better links to active business in the Spanish economy (through direct investment or simply licensing IPRs), then the United Kingdom seems to have taken better advantage of the system (a higher implemented patent rate and duration). In reality, if we check the implemented patents that extended more than 10 and 15 years, we see that, besides the United Kingdom, five other countries stood out from the rest and the system average: first the United States, and then Sweden, Switzerland, Belgium, and France. Germany and Austria were near the average; Italy, the Netherlands, and Canada below it.

If we focus now on foreign trademarking, a similar pattern emerges. Distinctive signs were and are the only industrial property that can be indefinitely extended as far as the renovation fees were paid. ${ }^{102}$ Thus, marks may last years, decades, or centuries; some can accumulate significant market value and back firms' success in the long run, and a handful can become global and turn into well-known enduring brands and corporations' essential intangible assets (i.e., ownership advantage). ${ }^{103}$ Table 7 shows the duration data for foreign trademarks granted in Spain between 1850 and 1916. That means that we were able to find out trademark expiration dates or even those still in force when we collected the database between 2000 and 2010. ${ }^{104}$ The United States and the United Kingdom were again the most effective IPR managers in Spain, if we pay heed to their trademarks' endurance. Both countries demonstrate persistence in trademarking in the European periphery and thus in maintaining IPRs for product distribution and commercialization. Between 11 and 12\% of US and UK trademarks that entered the Spanish market before 1916 lasted more than 80 years, and between 6 and $8 \%$ were in force at the beginning of the twenty-first century. The average for the entire Spanish trademark system was $4.1 \%$ in the first case and 2.4 in the second.

Furthermore, if we analyze the endurance of French marks in the long term, the data demonstrate a remarkable lack regarding the accumulation of added value on trademark assets. Although it would be necessary to qualify our first findings with information from the international and European trademark registries at the WIPO and the OHMI, ${ }^{105}$ ceteris paribus, French firms and businessmen do not seem to have achieved the same trademark management success in the long run as their Anglo-American counterparts, despite being the main foreign investors in the Spanish economy during the period studied. Even Germans, who used the Spanish trademark system profusely, fell behind the United States and the United Kingdom, 
although they clearly exceeded the French results. The rest of the countries took very few marks in Spain before 1916 to establish solid conclusions, although the endurance data for Swedish and Italian trademarks are also remarkable, and those for Austria, the Netherlands, and Belgium are not.

Table 9. Patents and trademarks in Spain from the most significant foreign countries by percentage of assignments and licenses

\begin{tabular}{lcclcc}
\hline & $\begin{array}{c}\text { Patents } \\
(1820-1939)\end{array}$ & & & $\begin{array}{c}\text { Trademarks } \\
(1850-1916)\end{array}$ \\
& Total & $\begin{array}{c}\text { Assignments } \\
\text { \& Licenses } \\
\text { \% }\end{array}$ & & Total & $\begin{array}{c}\text { Assignments } \\
\text { \& Licenses } \\
\%\end{array}$ \\
Sweden & 1,290 & 8.1 & United States & 693 & 35.9 \\
United States & 10,901 & 7.9 & United Kingdom & 1,534 & 34.2 \\
Netherlands & 1,736 & 7.4 & Sweden & 53 & 24.5 \\
United Kingdom & 11,698 & 7.2 & Italy & 51 & 19.6 \\
Austria & 1,474 & 7.2 & Germany & 1,520 & 17.6 \\
Germany & 18,898 & 5.8 & France & 1,341 & 11.8 \\
Canada & 324 & 4.9 & Austria & 96 & 9,4 \\
France & 19,643 & 4.5 & Switzerland & 78 & 9.0 \\
Switzerland & 3,853 & 4.3 & Netherlands & 23 & 4,3 \\
Italy & 3,708 & 4.2 & Belgium & 46 & 2,2 \\
Belgium & 2,555 & 3.0 & Canada & 9 & -- \\
\hline Patent system & $\mathbf{1 5 2 , 8 6 7}$ & $\mathbf{5 . 0}$ & Trademark system & $\mathbf{3 5 , 1 6 7}$ & $\mathbf{1 9 . 8}$ \\
\hline
\end{tabular}

(a) Although these are trademarks applied for between 1850 and 1916, they could have been licensed at any moment during their existence.

Source: See Figure 1

Table 9 rounds off our findings by showing the percentages of foreign IPR assignments and licenses during the periods studied. The aggregated data demonstrate, first, that there was more transference of trademarks than of patent rights: for an average of $5 \%$ of the documented assignments in the patent system, there were almost $20 \%$ among trademarks, a modality that could be indefinitely renewed and thus was subject to more property alterations, including inheritances or firm status shifts. Second, the United States and the United Kingdom were both very active in commercializing IPRs, as also occurred with Sweden, the Netherlands, Austria, and to a lesser extent Germany, in the case of patents, and with Sweden and Italy in that of trademarks. Finally, other main investors in the Spanish economy, such as France, Belgium, Switzerland, and Canada, remained below the average in IPR assignment rates.

These data could help to uncover distinct strategies related to foreign IPR management in the European periphery. Firms and industrialists from certain countries with a high rate of 
direct investment and businesses in Spain, such as France, Belgium, Switzerland, and Germany (see Table 1), may have been less motivated to license technologies and distinctive signs to competitors or local firms. However, firms, manufacturers, and traders from countries such as the United States, or even Sweden or the Netherlands, with fewer direct interests in Spain before WWII, although increasingly competent in technological and mercantile issues, may have found a noteworthy business in applying for and commercializing IPRs among domestic manufacturers or foreign residents. The exception is the United Kingdom, which, despite being a main investor in Spain (although decreasing from 1900 onwards), seems to have also developed such a market-oriented outlook on IPR business as the United States.

To sum up, our findings reveal, first, that among the main foreign investors in Spain, Anglo-Americans certainly stood out in IPR management during the period studied. Even though they were not the leaders in FDI, they took advantage of the opportunities provided by the Spanish IPR system, realizing the growing importance of intangible assets in an increasingly linked world. They reached higher rates of implemented patents (those which overcame the compulsory working clauses), enduring trademarks, and assignment businesses than France or Germany. The United States was especially successful in this policy and used it widely in Europe. In fact, French scholars underline that the major North American contribution to France during the first third of the twentieth century was technology transfer through patents and licenses. ${ }^{106}$ This confirms that US international expansion was preceded by a conscientious IPR strategy, which consists of both flooding patents and trademarks into Europe and other parts of the world and determinedly defending such intangible assets outwards. In that strategy, the increasing size, influence, and internationalization of US corporations seems essential.

Compulsory working and enduring data also suggest that French (and Belgian) investors may have neglected IPR management in Spain to a certain extent, at least in trademark-related issues. On the contrary, the science-and-technology-focused German industrial pattern and its yearning for external markets progressively favored patent and trademark effectiveness abroad, which undoubtedly influenced the gaining of ground in Spain against France before WWII and the improvement of economic results. ${ }^{107}$ Nevertheless, France has always been strongly implicated in the Spanish economy and, as we already know (Section 2), it reinforced its role as a main investor and platform of technology transfer during the second half of the twentieth century. In fact, France, Germany, the United States, the United Kingdom, Switzerland, Italy, Belgium, the Netherlands, and Sweden were, in this order, the origin of the main technology transfer contracts signed with Spanish firms during the 1960s and early 1970s. ${ }^{108}$

Finally, the empirical evidence shows that even on the European periphery, even in a lagging country with a hybrid IPR system, which fit the international standards on the one hand but had mechanisms for eluding intellectual monopolies that did not lead to direct investments in the domestic economy on the other, patent and trademark use and management were a key 
question for foreign investors from pioneering and developed nations. For different reasons and with distinct successes, they continuously applied for and obtained IPRs in Spain. Data from this section reveal that the majority of those IPR extensions to Spain may be made in a defensive way and were just a product of the processes of IPR internationalization and industrial expansion from the most advance economies. In fact, many of those patents and trademarks did not last particularly long, although they could also have had significant effects for foreign investors and exporters on assuring at least 3-4 years of total protection and on impeding later monopolies by domestic industrialists. Nevertheless, the data also show that an interesting percentage of successful patents and trademarks extended for a long time, which pointed to deliberate and proactive IPR strategies designed to support FDI or even designed for the growing business of buying and selling intangible assets: a thriving industry during the second half of the twentieth century as it is in the twenty-first.

\section{Concluding remarks}

We devoted this article to the theoretical and empirical analysis of the long-term links between FDI and IPRs, especially focusing on the case of Spain, a backward economy at the European periphery recipient of large FDI inflows from the most outward-looking North Atlantic economies during the last two centuries. Considering the OLI paradigm as a basic framework for the understanding of FDI decisions, it is possible to stand that there are ownership and location advantages regarding intangible assets administration. Furthermore, ownership advantages are related to innovative, mercantile, and organizational skills that include international IPR management competences. Similarly, particular location and receptivity factors regarding intangible asset protection, such as the character and scope of distinct domestic IPR institutions, must be taken into account. However, it is still not clear how such IPR managerial and institutional conditions fit in the jigsaw.

While some of these topics have profusely attracted IB scholars and, to a lesser degree, business and economic historians, the specific relations between FDI and IPRs have been only analyzed by the formers, especially focusing on how IPRs influence FDI in recent short-term periods. Unsurprisingly, the results lack permanent answers. As we have stated, there is conflicting theoretical and empirical evidence concerning the effects of strengthening IPRs on FDI. The main stream points that IPR reinforcing leads to increasing FDI, although other scholars' theoretical and empirical works suggest just the opposite. We strongly claim that more historical research should be conducted in order to offer fresh long-term evidence and new insights.

In fact, when the long-run is introduced in the analysis, FDI and IPRs seem to be distinct parts of the same process that co-evolved from the late-nineteenth century onwards as the international economy progressively developed. Furthermore, the evidences suggest that 
increasing IB and FDI were the sources for and not the effect of IPR extension. The 1883 International Union for the Protection of Industrial Property was just the beginning of a long path for global IPR enforcement that ended in today's WIPO. Such enforcement was developed when international exchanges of labor, capital, goods, and technologies also widened in the heat of the SIR and MNE emergence. As the world economy and corporations expanded, so did IPRs at the national, continental, and global levels. Moreover, the so-called second globalization has culminated in the 1994 TRIPS, one of the bases of the WTO that rules strong IPR controls and related trade sanctions to a never-seen scale. Throughout this process, developed and developing nations pursued distinct economic and IPR strategies. The former were always interested in standing up for protecting - and monopolizing - their increasing (corporate) intangible asset production; the latter, as in Spain in the past but also in all the countries that once upon a time were developing economies (including the mid-nineteenth-century United States), sought shortcuts for promoting industrialization and for impeding long foreign intellectual monopolies that did not lead to actual direct investments. Currently, however, we might be "kicking away the ladder," requiring of developing and underdeveloped economies things that we, now developed, hardly respected in the past. ${ }^{109}$

Concerning our long-term case study, our findings demonstrate, first, that despite the fact that the Spanish IPR system required actual investments, otherwise hindering foreign intellectual monopolies, FDI activity and foreign patent and trademark applications did not decrease during the period studied. Other evidence from the Netherlands (which rescinded the patent system between 1869 and 1912), Switzerland (which did not pass a patent law until 1888), and Denmark (which had essentially no protection before 1876 and weak protection thereafter) shows that low-level or no IPRs diminished neither domestic innovation rates although they were determined in certain directions ${ }^{110}$ - nor industrialization and foreign investment inflows. ${ }^{111}$ Thus, our historical evidence accords closely with those scholars who stand that FDI would have expanded to the same extent with low-level IPRs ${ }^{112}$ and that insufficient IPR protection does not reduce FDI. ${ }^{113}$

Second, our research also demonstrates that FDI and IPRs were strongly related in Spain during the nineteenth and the first half of the twentieth century, in the sense that they share the same source countries and similar sectorial patterns. FDI inflows to Spain came from nineteenth-century pioneers and first followers, mainly France, the United Kingdom, and Belgium, with increasing participation from Germany, other North European economies, such as Switzerland and the Netherlands, and progressively the United States. As France, the leader of FDI in Spain, lost ground from 1880 onwards, Germany and other newly industrialized countries gained it, especially in the most scientific-based industries. Thus long-term IPR data match the FDI evolution quite well. Before 1880, France totally dominated the patent and trademark system in Spain, followed by the United Kingdom, but after that date the increasing 
presence of German and US industrial property challenged the French leadership. On the eve of WWI, Germany surpassed France in taking both patents and trademarks, and the United States had rapidly grown at a pace even faster than its investments in the country, while the United Kingdom maintained its participation. Apparently, these last three countries, especially the new international challengers, Germany and the United States, gave much importance to intangible assets abroad. Science, technology, human capital, and knowledge of how to innovate and how to sell became essential in new heavy and intermediate industries with high added value: sectors such as machinery and equipment of every kind, chemicals, electricity, or metallurgy, which these newcomers had begun to lead internationally. In fact, FDI and foreign patenting in Spain were highly concentrated in those sectors, although the data also show significant patent activity in the textiles, food, beverage, and tobacco industries and the wide service sector. The analysis of foreign trademarks, which were mostly related to consumer products everywhere, also reveals a significant bias towards capital and intermediate goods.

Third, through the exploration of IPR licensing and IPR duration, by checking compulsory working clauses and installment payments, our work reveals that the United States and the United Kingdom significantly stood out from the rest as regards IPR length and assignment proportion, while France, Belgium, and even Germany were less effective in maintaining their rights in Spain and less inclined to commercialize them. ${ }^{114}$ Thus, we can state that, at least from a macro-level perspective, the countries with major FDI in Spain, such as the last-mentioned, were less worried about enlarging IPRs than others with less FDI, such as the United States, Sweden, the Netherlands, and even the United Kingdom, of which the major investments in Spain proportionally decreased from 1880 to 1914 . This fits well with the notion that direct investments may provide more control over innovation and marketing activities. In that case, IPR owners may not be interested in licensing technologies or distinctive signs to potential competitors or even may take less care of extending patents and trademarks beyond certain point; arguments that again match those of scholars who support that FDI would occur even with low-level or no IPRs and especially with those who stand that FDI increase intangible assets control over local IPR weaknesses. ${ }^{115}$

Finally, our findings suggest that IPR defense and enforcement turned into a key issue for Anglo-Americans and remarkably the United States, who seem to have realized early on the increasing significance of monopolizing enduring IPRs abroad as a global economic and managerial strategy, whether it precedes FDI or not. We cannot forget here that patent and trademark rights could also be negotiated and licensed to third parties and, therefore, become a profitable business. This fits well with some of Mansfield's findings for recent periods, which demonstrate that US companies are generally more worried on IPR protection abroad than other countries' firms. For instance, surveys from US chemical companies reveal a higher increasing concern on IPRs than German or Japanese MNEs in the same sector. In Mansfield's own words: 
US firms might be expected to require stronger protection before exposing or transferring their most advantage technology. ${ }^{116}$ Our work demonstrates that those key issues in the current global economy were early raised in the US international business agenda. A successful long-term strategy that the club of today's world technological and economic leaders has totally internalized.

\section{REFERENCES}

Adams, Samuel. "Intellectual Property Rights, Investment Climate and FDI in Developing Countries." International Business Research 3, no. 3 (2010): 201-9.

Aldcroft, Derek. The European Economy 1914-2000. London: Routledge, 2002.

Álvaro, Adoración. "Hízose el milagro. La inversión directa estadounidense y la empresa española (c. 1900-1975)." Investigaciones de Historia Económica 7, no. 3 (2011): 35868.

- - . "Inversión directa extranjera y formación de capacidades organizativas locales: un análisis del impacto de Estados Unidos en la empresa española (1918-1975)." Phd, Universidad Complutense de Madrid, Servicio de Publicaciones, 2011. http://eprints.ucm.es/12327/.

Arrow, Kenneth J. "Economic Welfare and the Allocation of Resources for Invention." In The Rate and Direction of Inventive Activity: Economic and Social Factors, 609-26. Cambridge, Mass: National Bureau of Economic Research, 1962.

Boldrin, Michele, and David K. Levine. Against Intellectual Monopoly. Cambridge: Cambridge University Press, 2008.

- - . "Market Size and Intellectual Property Protection." International Economic Review 50, no. 3 (2009): 855-881. doi:10.1111/j.1468-2354.2009.00551.x.

- - . "What's Intellectual Property Good For?" Revue Économique 64, no. 1 (2013): 29-53. doi:10.3917/reco.641.0029.

Bonin, Hubert, and Ferry De Goey, eds. American Firms in Europe: Strategy, Identity, Perception and Performance (1880-1980). Genève: Librairie Droz, 2009.

Broder, Albert. "Le rôle des intérêts étrangers dans la croissance économique de l'Espagne, 1815-1913 : Etat-entreprise et histoire." Université de Lilles, 1982.

- - - "Les investissements étrangers en Espagne au XIXe siècle." Revue d'histoire économique et sociale 54, no. 1 (1976): 29-63.

Bruland, Kristine. "Managing Foreign Operations: Babcock \& Wilcox in Europe, C. 1870-1920." In Essays on Industrialization in France, Norway and Spain, edited by Kristine Bruland and Jean-Marc Olivier, 93-112. Oslo: Unipub, 2005.

Cameron, Rondo E. La France et le developpement economique de l'Europe, 1800-1914. Paris: Éditions du Seuil, 1971.

Carreras, Albert, and Xavier Tafunell. "Spain: Big Manufacturing Firms between State and Market, 1917-1990." In Big Business and the Wealth of Nations, edited by Alfred Dupont Chandler, Franco Amatori, and Takashi Hikino, 277-308. Cambridge: Cambridge University Press, 1997.

Cebrián, Mar. "The Structure of Payments as a Way to Alleviate Contractual Hazards in International Technology Licensing." Industrial and Corporate Change 18, no. 6 (2009): 1135-60. doi:10.1093/icc/dtp016.

Chandler, Alfred Dupont. The Visible Hand: The Managerial Revolution in American Business. Cambridge, Mass: Belknap Press, 1977.

Chang, Ha-Joon. Kicking Away the Ladder. Development Strategy in Historical Perspective. London: Anthem Press, 2002. 
Chastagnaret, Gérard. L'Espagne, puissance minière: dans l'Europe du XIXe siècle. Madrid: Casa de Velázquez, 2000.

Cho, Kang Rae. Multinational Banks: Their Identities and Determinants. Ann Arbor, Mi: UMI Research Press, 1985.

Comín, Francisco. 150 años de historia de los ferrocarriles españoles: La nacionalización de las redes : RENFE y los ferrocarriles autonómicos. Madrid: Anaya, 1998.

Costa, María Teresa. La financiación exterior del capitalismo español en el s.XIX. Barcelona: Edicions Universitat Barcelona, 1983.

Diebolt, Claude, and Karine Pellier. Measuring the "ideas": Evidence from a New International Patent Database. Working Paper. AFC Working Papers. Association Française de Cliométrie, 2011. http://ideas.repec.org/p/afc/wpaper/11-04.html.

Dosi, Giovanni, Richard R. Nelson, and Sidney G. Winter. The Nature and Dynamics of Organizational Capabilities. Oxford: Oxford University Press, 2000.

Duguid, Paul, John Mercer, and Teresa da Silva Lopes. "Reading Registrations. An Overview of 100 Years of Trademark Registrations in France, the United Kingdom, and the United States." In Trademarks, Brands, and Competitiveness, edited by Paul Duguid and Teresa da Silva Lopes, 9-30. New York: Routledge, 2010.

Dunning, John H. International Production and the Multinational Enterprise. London; Boston: Allen \& Unwin, 1981.

Dunning, John H., and Rajneesh Narula. "The Investment Development Path Revisited. Some Emerging Issues." In Foreign Direct Investment and Governments: Catalysts for Economic Restructuring, edited by John H. Dunning and Rajneesh Narula. London and New York: Routledge, 1996.

Fear, Jeffrey R. Cartels and Competition: Neither Markets nor Hierarchies. Working Paper. Boston, Ma: Division of Research, Harvard Business School, 2006.

Federico, P. J. "Historical Patent Statistics." Journal of the Patent Office Society 46, no. 2 (1964): 89-171.

Gilbert, Richard, and Carl Shapiro. "Optimal Patent Length and Breadth." The RAND Journal of Economics 21, no. 1 (1990): 106-12. doi:10.2307/2555497.

Helpman, Elhanan. "Innovation, Imitation, and Intellectual Property Rights." Econometrica 61, no. 6 (1993): 1247-80. doi:10.2307/2951642.

Higgins, David M., and Geoffrey Tweedale. "Asset or Liability? Trade Marks in the Sheffield Cutlery and Tool Trades." Business History 37 (1995): 1-27. doi:10.1080/00076799500000088.

Hymer, Stephen. The International Operations of National Firms: A Study of Direct Foreign Investment. Boston, Ma: MIT Press, 1976.

Jones, Geoffrey. Multinationals and Global Capitalism: From the Nineteenth to the Twenty First Century. Oxford; New York: Oxford University Press, 2005.

Khan, B. Zorina. The Democratization of Invention: Patents and Copyrights in American Economic Development, 1790-1920. NBER Series on Long-Term Factors in Economic Development. Cambridge; New York: Cambridge University Press, 2005.

Kindleberger, Charles Poor. American Business Abroad: Six Lectures on Direct Investment. New Haven: Yale University Press, 1969.

- - . The World in Depression, 1929-1939. Los Angeles: University of California Press, 1986.

Kondo, Edson K. "The Effect of Patent Protection on Foreign Direct Investment." Journal of World Trade 29, no. 6 (1995): 97-112.

Kranakis, Eda. "Patents and Power: European Patent-System Integration in the Context of Globalization." Technology and Culture 48, no. 4 (2007): 689-728.

Lee, Jeong-Yeon, and Edwin Mansfield. "Intellectual Property Protection and U.S. Foreign Direct Investment." The Review of Economics and Statistics 78, no. 2 (1996): 181-86.

Lerner, Josh. "150 Years of Patent Office Practice." American Law and Economics Review 7, no. 1 (2005): 112-43. 
Lesser, William. "The Effects of Intellectual Property Rights on Foreign Direct Investment and Imports into Developing Countries in the Post TRIPs Era." IP Strategy Today 5 (2002): $1-16$.

Lopes, Teresa da Silva. Global Brands: The Evolution of Multinationals in Alcoholic Beverages. Cambridge; New York: Cambridge University Press, 2007.

Lopes, Teresa da Silva, and Paul Duguid, eds. Trademarks, Brands, and Competitiveness. New York: Routledge, 2010.

López-Morell, Miguel Ángel. The House of Rothschild in Spain, 1812-1941. Burlington, VT: Ashgate Pub., 2013.

Lubar, S. "The Transformation of Antebellum Patent Law." Technology and Culture 32, no. 4 (1991): 932-959.

MacLeod, Christine. Inventing the Industrial Revolution: The English Patent System, 1660-1800. Cambridge: Cambridge University Press, 1988.

MacLeod, Christine, Jennifer Tann, James Andrew, and Jeremy Stein. "Evaluating Inventive Activity: The Cost of Nineteenth-Century UK Patents and the Fallibility of Renewal Data." Economic History Review 56, no. 3 (2003): 537-62. doi:10.1111/j.14680289.2003.00261.x.

Mansfield, Edwin. Intellectual Property Protection, Direct Investment, and Technology Transfer: Germany, Japan, and the United States. IFC Discussion Papers. Washington, D. C.: World Bank Publications, 1995.

Moser, Petra. "How Do Patent Laws Influence Innovation? Evidence from Nineteenth-Century World's Fairs." American Economic Review 95, no. 4 (2005): 1214-36. doi:10.1257/0002828054825501.

Nadal, Jordi. El fracaso de la primera revolución industrial en España, 1814-1913. Barcelona: Crítica, 2009.

Nadal, Jordi, and Albert Carreras. Pautas regionales de la industrialización española (siglos XIX y XX). Barcelona: Ariel, 1990.

Nagaoka, Sadao. "Does Strong Patent Protection Facilitate International Technology Transfer? Some Evidence from Licensing Contracts of Japanese Firms." Journal of Technology Transfer 34, no. 2 (2009): 128-44.

Nelson, Richard R., and Sidney G. Winter. An Evolutionary Theory of Economic Change. Cambridge, Mass.: Harvard University Press, 1982.

Nicholson, Michael W. "The Impact of Industry Characteristics and IPR Policy on Foreign Direct Investment." Review of World Economics 143, no. 1 (2007): 27-54. doi:10.1007/s10290-007-0097-9.

Nunnenkamp, Peter, and Julius Spatz. "Intellectual Property Rights and Foreign Direct Investment: A Disaggregated Analysis." Review of World Economics 140, no. 3 (2004): 393-414.

O'Rourke, Kevin H., and Jeffrey G. Williamson. Globalization and History: The Evolution of a Nineteenth-Century Atlantic Economy. Boston, Ma: MIT Press, 1999.

Park, Walter G., and Douglas C. Lippoldt. "International Licensing and the Strengthening of Intellectual Property Rights in Developing Countries during the 1990s." OECD Economic Studies 40, no. 1 (2005): 7-48.

-- - The Impact of Trade-Related Intellectual Property Rights on Trade and Foreign Direct Investment in Developing Countries. OECD Papers: Special Issue on Trade Policy, 2003.

Penrose, Edith T. The Economics of the International Patent System. Baltimore: Johns Hopkins Press, 1951.

Plasseraud, Yves, and François Savignon. Paris 1883: Genèse Du Droit Unioniste Des Brevets. Paris: Litec, 1983.

Primo-Braga, Carlos A., and Carsten Fink. "The Relationship between Intellectual Property Rights and Foreign Direct Investment." Duke Journal of Comparative \& International Law 9, no. 1 (1998): 163-88. 
Puig, Núria, and Adoración Álvaro. “¿Misión imposible?: La expropiación de las empresas alemanas en España (1945-1975)." Investigaciones de Historia Económica 3, no. 7 (2007): 101-30.

Puig, Núria, and Rafael Castro. "Patterns of International Investment in Spain, 1850-2005." Business History Review 83, no. 3 (2009): 505-37. doi:10.1017/S0007680500002981.

Puig, Núria, and Javier Loscertales. "Las estrategias de crecimiento de la industria química alemana en España, 1880-1936: exportación e inversión directa." Revista de Historia Económica / Journal of Iberian and Latin American Economic History 19, no. 2 (2001): 345-82.

Sáiz, Patricio. "Did Patents of Introduction Encourage Technology Transfer? Long-Term Evidence from the Spanish Innovation System." Cliometrica 8, no. 1 (2014): 49-78. doi:10.1007/s11698-013-0094-2.

- - . "The Spanish Patent System (1770-1907)." History of Technology 24 (2002): 45-79.

Sáiz, Patricio, and Paloma Fernández-Pérez. "Catalonian Trademarks and the Development of Marketing Knowledge in Spain, 1850-1946." Business History Review 86, no. 2 (2012): 239-60. doi:10.1017/S0007680512000396.

Sáiz, Patricio, and David Pretel. "Why Did Multinationals Patent in Spain? Several Historical Inquiries." In Organizing Global Technology Flows. Institutions, Actors, and Processes, edited by Pierre-Yves Donzé and Shigehiro Nishimura, 39-59. New York: Routledge, 2014.

Sardà, Joan. La política monetaria y las fluctuaciones de la economía española en el siglo XIX. Barcelona: Editorial Alta Fulla, 1998.

Schankerman, Mark, and Ariel Pakes. "Estimates of the Value of Patent Rights in European Countries during the Post-1950 Period." The Economic Journal 96, no. 384 (1986): 1052-76.

Schenk, Catherine R. International Economic Relations since 1945. Abindong; New York: Taylor \& Francis, 2011.

Schiff, Eric. Industrialization without National Patents: The Netherlands, 1869-1912; Switzerland, 1850-1907. Princenton: Princeton University Press, 1971.

Schmookler, Jacob. Invention and Economic Growth. Cambridge: Harvard University Press, 1966.

Seyoum, Belay. "Patent Protection and Foreign Direct Investment." Thunderbird International Business Review 48, no. 3 (2006): 389-404. doi:10.1002/tie.20101.

- - . "The Impact of Intellectual Property Rights on Foreign Direct Investment." The Columbia Journal of World Business 31, no. 1 (1996): 50-59. doi:10.1016/S00225428(96)90006-X.

Smarzynska, Beata. "The Composition of Foreign Direct Investment and Protection of Intellectual Property Rights: Evidence from Transition Economies." European Economic Review 48, no. 1 (2004): 39-62.

Sureda, José Luis. El caso de "Barcelona Traction." Barcelona: Grafesa, 1959.

Tascón, Julio. La inversión extranjera en España. Madrid: Minerva, 2008.

Toca, Angel. "Electra del Besaya (1899-1911): la malograda introducción de la industria electrolítica en Cantabria." Catedra Nova, no. 17 (2003): 325-32.

Torres, Eugenio, ed. Cien empresarios españoles del siglo XX. LID Editorial. Madrid, 2000.

Tortella, Gabriel. Los orígenes del capitalismo en España: banca, industria y ferrocarriles en el siglo XIX. Madrid: Tecnos, 1995.

Tortella, Teresa. A Guide to Sources of Information on Foreign Investment in Spain 1780-1914. Amsterdam: International Institute of Social History, 2000.

Viñas, Ángel. Franco, Hitler y el estallido de la guerra civil: antecendentes y consecuencias. Madrid: Alianza Editorial, 2001.

Waterson, Michael. "The Economics of Product Patents." American Economic Review 80, no. 4 (1990): 860-69. 
Wernerfelt, Birger. "A Resource-Based View of the Firm." Strategic Management Journal 5, no. 2 (1984): 171-80.

Wilkins, Mira. The Emergence of Multinational Enterprise: American Business Abroad from the Colonial Era to 1914. Cambridge, Mass: Harvard University Press, 1970.

- - - The Maturing of Multinational Enterprise: American Business Abroad from 1914 to 1970. Cambridge, Mass: Harvard University Press, 1974.

-- - "US Business in Europe: An American Perspective." In American Firms in Europe: Strategy, Identity, Perception and Performance (1880-1980), edited by Hubert Bonin and Ferry De Goey, 35-67. Genève: Librairie Droz, 2009.

Williamson, Oliver E. The Economic Institutions of Capitalism. New York: Free Press, 1985.

Zamagni, Vera. Historia económica de la Europa contemporánea: de la revolución industrial a la integración europea. Barcelona: Crítica, 2011.

\section{NOTES}

\footnotetext{
${ }^{1}$ The so-called OLI paradigm: Dunning, International Production.

${ }^{2}$ Hymer, The International Operations.

${ }^{3}$ Nelson and Winter, An Evolutionary Theory; Wernerfelt, "A Resource-Based View”; Williamson, The Economic Institutions; Dosi, Nelson, \& Winter, The Nature and Dynamics.

${ }^{4}$ Dunning and Narula, "The Investment Development”, in Foreign Direct, eds. John H. Dunning \&

Rajneesh Narula, 3-4.

${ }^{5}$ Cho, Multinational Banks.

${ }^{6}$ Chandler, The Visible Hand, 375.

${ }^{7}$ Mansfield, Intellectual Property; Lee \& Mansfield, “Intellectual Property”; Lesser, “The Effects”; Smarzynska, "The Composition”; Seyoum, "Patent Protection”; Adams, "Intellectual Property.”

${ }^{8}$ Mansfield, Intellectual Property, 23; Lee \& Mansfield, “Intellectual Property,” 182.

${ }^{9}$ Helpman, “Innovation, Imitation,” 1275; Seyoum, “The Impact,” 57; and "Patent Protection,” 400.

${ }^{10}$ Nicholson, "The Impact of Industry”; Nagaoka, "Does Strong Patent."

${ }^{11}$ Nunnenkamp \& Spatz, "Intellectual Property”; Park \& Lippoldt, “International Licensing”; Nicholson, "The Impact of Industry."

${ }^{12}$ Boldrin and Levine, Against Intellectual Monopoly; Boldrin and Levine, "Market Size.”

${ }^{13}$ Boldrin \& Levine, "What's Intellectual Property,” 37-40.

${ }^{14}$ Kondo, "The Effect of Patent."

${ }^{15}$ Primo-Braga \& Fink, "The Relationship,” 172.

${ }^{16}$ Adams, "Intellectual Property," 203.

${ }^{17}$ Park and Lippoldt, The Impact; Nunnenkamp \& Spatz, "Intellectual Property."

${ }^{18}$ Jones, Multinationals and Global Capitalism, 4-15.

${ }^{19}$ O’Rourke \& Williamson, Globalization \& History.

${ }^{20}$ Zamagni, Historia económica.

${ }^{21}$ Aldcroft, The European Economy.

${ }^{22}$ Kindleberger, The World in Depression.

${ }^{23}$ Fear, Cartels and Competition.

${ }^{24}$ See the Bretton Woods framework and the Americanization of the European economy in Wilkins, The Maturing.

${ }^{25}$ Jones, Multinationals and Global Capitalism, 22.

${ }^{26}$ MacLeod, Inventing the Industrial Revolution, 16-17.

${ }^{27}$ Lubar, “The Transformation," 934-35.

${ }^{28}$ Plasseraud and Savignon, Paris 1883, 186-87.

${ }^{29}$ Data from P. J. Federico "Historical Patent," 97-11., who provides information on the first patent laws for 44 countries.

${ }^{30}$ Higgins \& Tweedale, “Asset or Liability?”; Duguid, Mercer, \& Lopes, “Reading Registrations”, in

Trademarks, Brands, eds. Paul Duguid \& Teresa da Silva Lopes, 12.
} 
${ }^{31}$ Duguid, Mercer, \& Lopes, “Reading Registrations”, in Trademarks, Brands, eds. Paul Duguid \& Teresa da Silva Lopes, 28, note 2.

${ }^{32}$ See Section 4, paragraphs 3-5, in this work.

${ }^{33}$ Pages 45-59.

${ }^{34}$ The Convention was initially signed by eleven countries in 1883 (Belgium, Portugal, France, Guatemala, Italy, the Netherlands, San Salvador, Serbia, Spain, and Switzerland) and by another three in 1884, when ratifications were exchanged (the United Kingdom, Tunisia, and Ecuador). See "Convenio de 20 de marzo de 1883" in Colección Legislativa de España, T. CXXXIII.

${ }^{35}$ Six months for patents and three for trademarks and industrial design (twelve and six months, respectively, after the 1900 treaty revision).

${ }^{36}$ See Penrose, The Economics, 79-87.

${ }^{37}$ All the treaties mentioned, contracting parties, joining date of each country, and further information are available at http://www.wipo.int/treaties/en

${ }^{38}$ The European Union, NAFTA, Andean Pact, Mercosur, or Cafta-DR, which, to different extents, included IPR agreements.

${ }^{39}$ Community trademarks and designs provide protection in the whole European Union with no country selection possibility. On the contrary, the European patent protects only in countries designed by the applicant, which may also reach the whole Union. Recently, the path to the Community patent has been approved (2012) to achieve the same integration goals as trademarks, although it has not been ratified by Spain and Italy. For further information see: Council Regulation (EC) No. 40/94 of December 20, 1993 on the Community trademark; Council Regulation (EC) No. 6/2002 of December 12, 2001 on Community designs (and revisions); the European Patent Convention of 1973 (revised in 2007); Regulation (EU) No. 1257/2012 of the European Parliament and of the Council of December 17, 2012 implementing enhanced cooperation in the area of the creation of unitary patent protection; Council Directive 91/250/EEC of May 14, 1991 on the legal protection of computer programs; and Council Directive 93/98/EEC of October 29, 1993 harmonizing the term of protection of copyright and certain related rights.

${ }^{40}$ Annex 1C of the Marrakesh Agreement Establishing the World Trade Organization, signed in Marrakesh, Morocco, on April 15, 1994.

${ }^{41}$ Schenk, International Economic Relations, 105.

${ }^{42}$ Kranakis, "Patents and Power," 689.

${ }^{43}$ Gilbert \& Shapiro, "Optimal Patent”; Waterson, "The Economics.”

${ }^{44}$ Broder, "Le rôle des intérêts"; Tortella, Los orígenes; Nadal, El fracaso.

${ }^{45}$ Broder, "Les investissements," 62; Costa, La financiación; Sardà, La política monetaria, 250-63.

${ }^{46}$ Tortella, A Guide. For a list of all the archives and sources see the Introduction, pages iii to v.

${ }^{47}$ Broder, "Les investissements"; "Le rôle des intérêts"; Costa, La financiación; Tortella, Los orígenes; Nadal, El fracaso.

${ }^{48}$ The Credit Mobilier for the latter and the Sociedad Española Mercantil e Industrial for the Rothschilds. See Cameron, La France; López-Morell, The House.

${ }^{49}$ Torres, Cien empresarios.

${ }^{50}$ Carreras \& Tafunell, "Big Business”, in Big Business, eds. Alfred Dupont Chandler, Franco Amatori, \& Takashi Hikino, 293; Puig \& Loscertales, "Las estrategias”; Puig \& Castro, "Patterns of International.”

${ }^{51}$ Broder, "Le rôle des intérêts," 854-941, 1660-1803; Comín, 150 años; Chastagnaret, L’Espagne.

${ }^{52}$ Broder, "Les investissements," 43-58; Costa, La financiación, 87-89-156.

${ }^{53}$ Sáiz, "The Spanish,” 48-49.

${ }^{54}$ Duguid, Mercer, \& Lopes, "Reading Registrations”, in Trademarks, Brands, eds. Paul Duguid \& Teresa da Silva Lopes, 10; Sáiz \& Fernández-Pérez, “Catalonian Trademarks,” 243.

${ }^{55}$ Puig \& Castro, "Patterns of International”; López-Morell, The House.

${ }^{56}$ Chastagnaret, L'Espagne; Tortella, A Guide.

${ }^{57}$ Broder, "Le rôle des intérêts"; Tortella, A Guide.

${ }^{58}$ We could only provide some data from Tascón, La inversión, although they are quite arguable because of the sources and years. According to those statistics, France led the FDI with more than 50\% in 1936 and more than $47 \%$ in 1938.

${ }^{59}$ Including Sociedad Electro-Química de Flix, Industrias Químicas Reunidas, Cloratita, La Unión Química y Lluch/Unicolor, La Química Comercial y Farmacéutica, Instituto Behring de Terapéutica Experimental, Fabricación Nacional de Colorantes y Explosivos, and Agfa Foto Puig \& Álvaro, “¿Misión imposible?”

${ }^{60}$ Archivo de la Cámara de Comercio Francesa de Madrid, ACCFM. 1929. Boletín 320:31. 
${ }^{61}$ Viñas, Franco, Hitler; Puig \& Álvaro, “¿Misión imposible?”; Puig \& Castro, “Patterns of International."

${ }^{62}$ Álvaro, “Inversión directa," 104, Table 3.1.

${ }^{63}$ See, for instance, Toca, "Electra del Besaya", on US capital in the first establishment for electrolytic caustic soda production in the north of Spain (located in Bárcena de Pie de Concha).

${ }^{64}$ Wilkins, The Maturing, 56.

${ }^{65}$ Álvaro, "Hízose el milagro."

${ }^{66}$ Puig \& Castro, "Patterns of International," 531.

${ }^{67}$ Arrow, "Economic Welfare”, in The Rate and Direction.

${ }^{68}$ Through the Decree of October 2, 1820 and the Royal Decree of March 26, 1826, that was in force until a new patent law was passed in 1878 .

${ }^{69}$ The Royal Decree of January 4, 1834, which was substituted with the Law of June 10, 1847 and this

with the Law of January 10, 1879.

${ }^{70}$ The Royal Decree of November 20, 1850.

${ }^{71}$ The Patent Law of July 30, 1878.

${ }^{72}$ The Law of May 16, 1902 and the Royal Decree-Law of July 26, 1929.

${ }^{73}$ The Law 11/1986 of March 20; the Law 32/1988 of November 10; the Law 17/2001 of December 7; the Law 20/2003 of July 7; the Law 22/1987 of November 11; and the Royal Legislative-Decree 1/1996 of April 12.

${ }^{74}$ Sáiz, “The Spanish”; Sáiz \& Fernández-Pérez, “Catalonian Trademarks,” 245; Sáiz, “Did Patents.”

${ }^{75}$ Khan, The Democratization, 57 and 257.

${ }^{76}$ Diebolt and Pellier, Measuring The "ideas," 13.

${ }^{77}$ Sáiz, "Did Patents."

${ }^{78}$ Penrose, The Economics, 70, note 21.

${ }^{79}$ See http://historico.oepm.es for further information.

${ }^{80}$ Nadal \& Carreras, Pautas regionales; Nadal, El fracaso.

${ }^{81}$ Sáiz, "The Spanish."

${ }^{82}$ See note ¡Error! Marcador no definido.

${ }^{83}$ See http://edison.rutgers.edu/list.htm (accessed September 2013).

${ }^{84}$ Bruland, "Managing Foreign”, in Essays on Industrialization, eds. Kristine Bruland \& Jean-Marc Olivier.

${ }^{85}$ Wilkins, The Emergence, 106. See also Boning \& Goey, American Firms, especially chapters 3 to 9, for a general view on the first US investments in several European countries.

${ }^{86}$ Jones, Multinationals and Global Capitalism, 258-60.

${ }^{87}$ Wilkins, “US Business”, in American Firms, eds. Hubert Bonin \& Ferry De Goey, $38-41$.

${ }^{88}$ The Canadian presence in Spain was on account of this corporation, in which other countries also participated. For further information see Sureda, El caso.

${ }^{89}$ Mansfield, Intellectual Property, 23; Lee \& Mansfield, “Intellectual Property,” 182.

${ }^{90}$ Besides Mansfield, Intellectual Property; Lee \& Mansfield, "Intellectual Property", this is also quite consistent with Petra Moser's findings on distinct industries' propensity to patent during the nineteenth century: Moser, “How Do Patent," 1220-1221 and Table 2.

${ }^{91}$ Patents have been classified following Schmookler's classical method, which consists of grouping the inventions according to the sector in which the new technology would make its impact (see Schmookler, Invention and Economic Growth, 20-23. Multi-sectorial and general machinery or procedures are grouped into "machinery and equipment." To improve such a system, we have combined sectorial with WIPO's technical classification (International Patent Classification). For further information on the kind of invention grouped in each sector see Sáiz "The Spanish,” 63-67.

${ }^{92}$ These goods have been classified according to the Nice International Classification of Goods and Services edited by the WIPO. The Nice classes have been grouped by economic sector as follows: textiles: 18 and 22-27; beverages: 32-33; chemicals: 1-5 and 17; tobacco: 34; food: 29-30; paper and graphic arts: 16; machinery and equipment: 7-11; arms industry: 13; basic metals and mining: 6 and 14; agriculture and cattle farming: 31; construction (including lumber): 19 and 37; services (including household goods, toys, musical instruments): 15, 20, 21, 28, 35, 36, and 39-45; transport (vehicles): 12; and communication: 38 .

${ }^{93}$ Lopes \& Duguid, Trademarks, Brands, 9-30.

${ }^{94}$ Sáiz \& Fernández-Pérez, “Catalonian Trademarks,” Table 2.

${ }^{95}$ Kindleberger, American Business; Hymer, The International Operations.

${ }^{96}$ Sáiz, “Did Patents,” Figure 2. 
${ }^{97}$ Schankerman \& Pakes, "Estimates of the Value."

${ }^{98}$ MacLeod et al., "Evaluating Inventive Activity."

${ }^{99}$ The 1820 law established a two-year period to implement the patent, which was reduced to one in 1826, returned to two in 1878, and set at three from 1902 onwards.

${ }^{100}$ Before 1878, the patent holder had to pay the total cost of the chosen monopoly in advance for 5,10 , or 15 years, but a new law passed that year introduced progressive annual installments.

${ }^{101}$ Although not specifically mentioned in the 1850 trademark Decree it was a usual practice, as this law required a factory or establishment to be opened in Spain and the goods to be commercialized under a registered trademark. The 1902 law included the abandonment (during three years) as a cause for trademark rights to expire. Abandonment for one year was also included in a previous 1882-1883 trademark law project that was eventually passed for Cuba and Puerto Rico only (Royal Decree of August 21, 1884). Finally, the 1929 law increased the abandonment period to five years.

${ }^{102}$ The Spanish 1850 Decree did not define any duration, but the 1902 law established 20 years (through 5-year installments) and then 5-year renewals. The 1988 and 2001 laws reduced the duration to 10 years renewable by 5 -year and 10-year payments, respectively.

${ }^{103}$ Lopes, Global Brands.

${ }^{104} 36,000$ trademark files progressively analyzed between 2000 and 2010.

${ }^{105}$ We work with trademarks presented in the national path. Thus, some marks, even apparently extinguished ones, might have been deposited or registered again through the international trademark system developed from 1891 onwards (see Section 2). Those marks were not added to the national files in so far as once they were sent by the International Bureau (WIPO) to the designated country's patent and trademark office, they automatically came into effect if there were no legal oppositions or complaints in the period established (a year), usually generating a new trademark collection. The same could be said about Community trademarks, in force in the European Union since 1994, which may have favored the abandonment of national paths for one integrated registry at the Office for Harmonization in the Internal Market (OHMI). Although it would be extremely interesting to cross national with international WIPO and European OHMI data, that is an impossible task today because of the amount of information that would have to be checked. Despite this difficulty, scholars should take this into account for case studies. ${ }^{106}$ Bonin \& Goey, American Firms, 95-101.

${ }^{107}$ Puig and Castro, "Patterns of International," 532-33.

${ }^{108}$ Cebrián, “The Structure,” Table 2.

${ }^{109}$ Chang, Kicking Away.

${ }^{110}$ Moser, "How Do Patent."

${ }^{111}$ Schiff, Industrialization.

${ }^{112}$ Boldrin and Levine, "What's Intellectual Property."

${ }^{113}$ Helpman, "Innovation, Imitation," 1275; Seyoum, "The Impact," 57; and "Patent Protection," 400.

${ }^{114}$ If we analyze corporate IPRs separately, this must be qualified. Aggregately, MNEs from countries with more direct investments (France, Belgium, and the UK) in the Spanish economy improved their patent management (greater implementation rate and length) in comparison with US or German companies, which still have higher licensing rates than the formers, as demonstrated by Sáiz \& Pretel "Why Did Multinationals", in Organizing Global, eds. Pierre-Yves Donzé \& Shigehiro Nishimura. ${ }^{115}$ Chandler, The Visible Hand, 374-76; Nicholson, “The Impact of Industry”; Nagaoka, “Does Strong Patent."

${ }^{116}$ Mansfield, Intellectual Property, 15. 